\title{
Rice (Oryza sativa L.) Establishment Techniques and Their Implications for Soil Properties, Global Warming Potential Mitigation and Crop Yields
}

\author{
Md. Khairul Alam 1,2,*(D), Richard W. Bell ${ }^{2}\left(\mathbb{D}\right.$, Mirza Hasanuzzaman $^{3}\left(\mathbb{D}\right.$, N. Salahin ${ }^{1}$, \\ M.H. Rashid ${ }^{1,4}$, Nadia Akter ${ }^{5}$, S. Akhter ${ }^{1}$, Mahammad Shariful Islam 1,6 , S. Islam 1,2, \\ S. Naznin ${ }^{1}$, M.F.A. Anik ${ }^{1}$, Md. Mosiur Rahman Bhuyin Apu ${ }^{1}$ (D) Hasib Bin Saif ${ }^{1}$, M.J. Alam ${ }^{1}$ \\ and Mst. Fatima Khatun ${ }^{1}$ \\ 1 Bangladesh Agricultural Research Institute, Gazipur 1701, Bangladesh; nsalahin13@gmail.com (N.S.); \\ mdharunur.rashid@uon.edu.au (M.H.R.); sohela_akhter@yahoo.com (S.A.); \\ sharifultasim@gmail.com (M.S.I.); sislambau4@gmail.com (S.I.); nazninsau@gmail.com (S.N.); \\ farid.anik.ahmmed@gmail.com (M.F.A.A.); opu128@gmail.com (M.M.R.B.A.); \\ hasib_1958@yahoo.com (H.B.S.); jahangirhstu97@gmail.com (M.J.A.); mfkhatun79@gmail.com (M.F.K.) \\ 2 Agriculture Discipline, College of Science, Health, Engineering and Education, Murdoch University, \\ Perth WA-6150, Australia; R.Bell@murdoch.edu.au \\ 3 Department of Agronomy, Faculty of Agriculture, Sher-e-Bangla Agricultural University, \\ Dhaka 1207, Bangladesh; mhzsauag@yahoo.com \\ 4 Global Centre for Environmental Remediation (GECR), Faculty of Science, University of Newcastle, \\ Callaghan 2308, NSW, Australia \\ 5 Bangladesh Rice Research Institute, Gazipur 1701, Bangladesh; nadia.akter21@yahoo.com \\ 6 Department of Crop Science, Universiti Putra Malaysia 43400 UPM Serdang, Selangor, \\ Darul Ehsan-43400, Malaysia \\ * Correspondence: khairul.krishi@gmail.com
}

Received: 10 April 2020; Accepted: 19 June 2020; Published: 22 June 2020

Abstract: Rice-based intensive cropping systems require high input levels making them less profitable and vulnerable to the reduced availability of labor and water in Asia. With continuous conventional puddled rice transplanting, the situation is exacerbated by damaged soil structure, declining underground water and decreasing land and water productivity. To minimize these negative effects a range of new crop establishment practices have been developed (zero tillage, dry direct seeding, wet direct seeding, water seeding, strip planting, bed planting, non-puddled transplanting of rice, mechanical transplanting of rice crop and combinations thereof) with varying effects on soil health, crop productivity, resource saving and global warming mitigation potential. Some of these allow Conservation Agriculture (CA) to be practiced in the rice-based mono-, double- and triple cropping systems. Innovations in machinery especially for smallholder farms have supported the adoption of the new establishment techniques. Non-puddling establishment of rice together with increased crop residue retention increased soil organic carbon by $79 \%$ and total $\mathrm{N}$ (TN) in soil by $62 \%$ relative to conventional puddling practice. Rice establishment methods (direct seeding of rice, system of rice intensification and non-puddled transplanting of rice) improve soil health by improving the physical (reduced bulk density, increased porosity, available water content), chemical (increased phosphorus, potassium and sulphur in their available forms) and biological properties (microbiome structure, microbial biomass $C$ and $N$ ) of the soil. Even in the first year of its practice, the non-puddled transplanting method of rice establishment and CA practices for other crops increase the productivity of the rice-based cropping systems. Estimates suggest global warming potential (GWP) (the overall net effect) can be reduced by a quarter by replacing conventional puddling of rice by direct-seeded rice in the Indo-Gangetic Plains for the rice-based cropping system. Moreover, non-puddled transplanting of rice saves $35 \%$ of the net life cycle greenhouse gases (GHGs) compared with the conventional practice by a combination of decreasing greenhouse gases emissions from soil and increasing soil organic 
carbon (SOC). Though the system of rice intensification decreases net GHG emission, the practice releases 1.5 times greater $\mathrm{N}_{2} \mathrm{O}$ due to the increased soil aeration. There is no single rice establishment technology that is superior to others in all circumstances, rather a range of effective technologies that can be applied to different agro-climates, demography and farm typologies.

Keywords: conservation agriculture; direct seeded rice; economics; greenhouse gas; non-puddled transplanting; puddled transplanting

\section{Introduction}

Future global food security depends on the continued success of rice production in Asia. Though rice production has shown a consistent increase since 2002 [1], it faces major challenges: The increasing demand for rice versus declining growth in yield and harvested area; soil fertility and productivity decline of intensive rice-based cropping systems [2]; depletion and or limitations of natural resources (soil and water) for rice production; plateauing of yield potential of recently released cultivars; rice crop establishment in rice-upland cropping systems; abiotic stresses (salinity, low temperature and drought); biotic stresses, the low income from rice production and changing socio-economic conditions $[3,4]$.

One of the regions where these challenges are evident is the rice-wheat cropping system in Indo-Gangetic Plains (IGP) of South Asia which covers about 13.5 M ha in Pakistan, Nepal, India, and Bangladesh [5]. Due to growing populations, additional rice productivity in the IGP is needed [6]. Both varietal improvement and soil fertility improvement [7] including soil management practices such as CA are central to increased rice production in the IGP. In the IGP and in other intensive rice-growing areas where wetland rice is grown in upland crop-rice cropping systems, establishing all component crops by following CA practices remains a challenge [7]. Farmers in the IGP currently prefer conventional practices of rice crop establishment to CA practices, even when they use zero tillage (ZT) and residue retention for the upland crops.

Rice consumes around $27 \%$ of the world total fresh water withdrawal [8,9]. For wetland rice production, puddling alone requires $30 \%$ of the crop water consumption [10]. Predictions indicate that 17-22 M ha of irrigated rice area in Asia will face water scarcity [11] by 2025, necessitating water-saving options to be practiced widely.

Manual rice transplanting requires $25-50$ person-days ha ${ }^{-1}$ [12], while the size of the workforce in agriculture declined by nearly 30 million between 2004-05 and 2011-12 [13] due to rapid economic growth in Asia in non-agricultural sectors [13] and increased labor wages [14].

Wetland rice production contributes almost $12 \%$ of anthropogenic methane and $55 \%$ of agriculturally-sourced greenhouse gas (GHG) emissions in the world [15].

Solutions to all problems can be found in modifications of crop establishment practices $[6,7,16,17]$. Among the crop production factors, tillage alone contributes up to $20 \%$ of crop production costs [18] and strongly influences soil properties [7]. Novel resource-saving technologies are, therefore, being developed to cope with these factors influencing cultivation of all crops including rice in the intensive crop growing areas $[6,7,19,20]$. Mechanical direct-seeding and transplanting under non-puddled/non-flooded conditions have been developed and evaluated by researchers in collaborations with farmers [19-21].

In addition, rice and upland crops are grown in a sequence with repeated cycling between anaerobic and aerobic conditions [22]. The contrasting environments alter the soil C and N cycles, GHG emissions, soil chemical and biological properties [22]. Chakraborty et al. [6] reviewed global data of soil properties, $\mathrm{C}$ and $\mathrm{N}$ cycling and greenhouse gas implications under emerging and conventional practices of crop production. However, the alterations in C and $\mathrm{N}$ cycling and GHG emissions from soils under conventional and promising CA practices have not been quantified in the intensively 
cropped Eastern Gangetic Plains (EGP) $[6,23]$. The literature also lacks $C$ footprint data of the rice-based cropping systems when CA practices sequester $C$ from the atmosphere into long-lived SOM pools in the subtropical humid region [24]. Some details of the practices and their implications for soil properties, $\mathrm{C}$ and $\mathrm{N}$ cycling and GHGs are given as follows.

\section{Trends in Rice Crop Establishment Practices in the Rice Growing Areas}

\subsection{Puddling}

There are both positive and negative results from transplanting following puddling of soil with wet tillage operations [25]. Puddling is done to reduce water losses by percolation, to control weeds, to establish rice seedling easily and to increase nutrient availability [26,27]. However, this method of rice establishment is under threat due to shortages of land, water and labor. Apart from the above factors, the demand for cropping system intensification and for high yielding short duration varieties are also driving changes in rice establishment technologies $[6,28]$.

\subsubsection{General Background}

In most cropping systems, tillage of the soil with excess moisture results in damage to soil structure which delays sowing which may incur yield loss. In the lowland wetland rice system, puddling of wet soil is a deliberative practice for the purpose of destroying the structure of upper layer of soil. It is the most common practice of lowland rice establishment in Asian countries. To make the matter worse, before puddling of soil by wet tillage operations, crop residues are removed from or burned on the field [29]. Farmers puddle soil purposefully to control weed, to make seedling transplanting easy and to keep water standing (to reduce loss of water and nutrients by deep percolation) [30].

\subsubsection{Tradeoffs of Puddling on Soil Physical Properties}

Puddled transplanting of rice degrades physical properties of soils [31]. The physical degradation of soil due to tillage includes soil structural destruction (aggregates breaking into small-aggregates and finally into small particles) [32], increase in soil penetration resistance and bulk density [33], water holding capacity and porosity $[16,33]$. The soil structural stability determines the degradation intensity due to puddling [32]. However, the succeeding crop faces severe obstacles and requires higher energy and labor costs for tillage [34,35]. Aggarwal et al. [36] conducted an experiment on puddling of sandy loam soil and reported that bulk density (BD) of the $0-30 \mathrm{~cm}$ soil layer increased with puddling level. Formation of the subsurface compacted layer possibly led to reduced percolation rates through the soil. Jat et al. [37] conducted experiments by employing laser-assisted precision land leveling and traditional land leveling with a number of crop establishment practices: Conventional puddled-transplanted rice and conventional-tillage (CT) wheat; zero-till direct drill-seeded rice and wheat after no-tillage; conventional-till direct drill-seeded rice and wheat after $\mathrm{CT}$; raised beds with no-tillage for direct-seeded rice and wheat on beds. They reported that the puddling of rice soil followed by tillage for upland crops had higher BD and penetration resistance (PR) and cone index in 10-15 and 15-20 cm soil layers due to compaction caused by the repeated wet tillage in rice. However, they recorded that the steady-state infiltration rate and soil aggregation $(>0.25 \mathrm{~mm})$ were higher under permanent beds and double ZT and lower in the CT system. Alam et al. [16] and Shukla et al. [38] in another study in the Indo-Gangetic Plain found that intensive tillage decreased soil porosity and entry of water in soil by infiltration by disrupting soil pores. Besides, by increasing clay distribution at the interface of puddled and undisturbed layer below, a hard ploughpan forms at 10-20 cm soil depth [39]. The ploughpan formed at the shallow soil layer disrupts pore sizes and hydraulic conductivity. While initially puddling of soil may decrease the PR and cone index, the subsidence of the puddled soil increases the BD and the PR again leading to decreased hydraulic conductivity after several days or months [39]. 


\subsubsection{Tradeoffs of Puddling on Soil Chemical Properties}

The anoxic conditions that rapidly develop in puddled, inundated soils regulate the chemical properties of soil. Saroch and Thakur [40] attributed the change in soil $\mathrm{pH}$ toward neutral values to the submergence caused by puddling of soil rather than to puddling of soil, per se. They also reported that available $\mathrm{N}$ content of the soil was varied due to puddling. Ponnamperuma [41] reported that puddling of soil increased available $\mathrm{N}$ which was attributed to increased residence time of available $\mathrm{NH}_{4}-\mathrm{N}$ due to anoxia and reduced loss by leaching. Alam et al. [42] observed that while conventional puddling of soil increased mineralization up to 60 days after transplanting, subsequent uptake and mineralization rate was slower in CT than non-puddling of soil. The initial elevated mineralization makes it possible that more $\mathrm{N}$ loss occurred under $\mathrm{CT}$.

Even more $\mathrm{N}$ is released when tillage coincides with periods of high soil temperature and/or moderate soil moisture [23,43]. The excess mineralized $\mathrm{N}$ after fulfilling the low demand of $\mathrm{N}$ by crops at the initial stage of crop might end up in loss via denitrification, nitrate leaching, ammonia volatilization or surface runoff [44,45]. Saroch and Thakur [40] also reported to have increased available $P$ content after puddling. Bibhash et al. [46] recorded similar results of increased P availability under puddled transplanting which Singh et al. [47] also attributed to release of $P$ from sorption (i.e., increase in $\mathrm{P}$ diffusion). However, exchangeable $\mathrm{K}$ and cation exchange capacity (CEC) of the soil were not varied due to puddled transplanting of rice. Irrespective of puddling and non-puddling of soil, when soils are comparatively wet, absorbed P, K and other cations come into soil solution. Similarly, Scheltema [29] and Ponnamperuma [41] stated that puddled transplanting of rice helped release monovalent and divalent cations from the absorbed state into soil solution, increase $\mathrm{pH}, \mathrm{CEC}$ and $\mathrm{CO}_{2}$ density in soil and accrue ammonium- $\mathrm{N}$ and organic substances in the puddled soil.

\subsubsection{Tradeoffs of Puddling on Soil Carbon Cycle and Soil Organic Matter}

Conventional puddled transplanting of rice followed by tillage for upland crops are the major source of greenhouse gas emissions due to increased loss of $C$ and $N$ via gaseous ways [48]. Generally, conventional puddling of soil for rice transplanting accelerates turnover of soil organic matter (SOM) in soil aggregates [49]. Banerjee et al. [50] recorded increased SOC in puddled soil than the non-puddled treatments in both the years of their experiment in the IGP. The repeated wet tillage operations for puddling break down soil aggregates into soil particles which enhance microbial activities for decomposition of aggregate associated SOM and thereby increase availability of SOC [51]. Alam et al. [52] also reported higher water soluble C (WSC) and higher decomposition rates of SOC in puddled soils than soils under non-puddled conditions after 5 years of study. The increased WSC under puddled conditions might lead to microbial decomposition during rice growth period as well as during succeeding crop grown under conventional tillage [53]. The accumulation of SOC depends not only on soil disturbance intensity but also on anaerobic soil conditions [54], and composition of organic residues (lignin and phenol) retained in the soil [52].

\subsubsection{Tradeoffs of Puddling on Soil Biological Properties}

Patra et al. [55] highlighted results of a field experiment conducted in the Lower Gangetic Plain of India which revealed that light puddling soil (puddling up to $5 \mathrm{~cm}$ depth without inversion with a wooden country plough with an iron cutting edge) brought about the highest MBC and microbial biomass $\mathrm{N}$ (MBN) compared to intensive puddling (puddling up to $15 \mathrm{~cm}$ depth with inversion by a rotary power tiller). Gunapala and Scow [56] attributed the increased MBC and MBN to increased microbial activity and availability of substrates under favorable temperature prevailing in puddled soil for transplanted rice [57]. When it is conventional puddled transplanting of rice with residue removal, the different scenarios were recorded by many researchers in rice-based cropping systems. Jat et al. [58] conducted experiment by using climate smart agriculture (CSA) practices. After five years, conventional puddling of rice followed by tillage for wheat (conventional scenario) had lower 
MBC, MBN, dehydrogenase activity (DHA), alkaline phosphatase activity (APA) and $\beta$-glucosidase over CSA based rice-wheat cropping. For example, conventional puddling of rice and full tillage for wheat had around $42 \%$ lower MBC, 79\% lower MBN, 58\% lower APA and 14\% lower DHA at 0-15 cm depth than CSA based scenarios. These lower MBC, MBN and enzyme activities in puddled soils might be attributed to unfavorable soil temperature and soil moisture prevailing under conventional scenario [59]. Disturbance of soil by puddled transplanting of rice had higher microbial biomass $C$ $(\mathrm{MBC})$ in soil than $\mathrm{MBC}$ in soils under non-puddled rice. Banerjee et al. [50] recorded 19\% increase in $\mathrm{MBC}$ in puddled soil amended with farmyard manure or green manure compared to chemical fertilizers and puddling. Alam et al. [7] also recorded the similar results of increasing MBC in soil under conventional puddling and addition of previous crop residues.

\subsubsection{Tradeoffs of Puddling on GHG and Climate Change Mitigation}

Puddling of rice soil followed by flooding resulted in emission of around $2.6 \mathrm{t} \mathrm{CO}_{2}$-eq ha ${ }^{-1}$ from soils within the first few weeks [60]. Methane $\left(\mathrm{CH}_{4}\right)$ and nitrous oxide $\left(\mathrm{N}_{2} \mathrm{O}\right)$ are the principal GHGs emitting from rice fields. The reduced soil layer in puddled soils with very low redox potential induced $\mathrm{CH}_{4}$ synthesis and emission [61] while the oxidized layer present at the interface of soil and water causes the emission of $\mathrm{N}_{2} \mathrm{O}$ [41]. The availability of $\mathrm{C}$ substrates (e.g., straw or organic amendments) accelerate the survival of methanogens and the low redox potential are both driving factors for $\mathrm{CH}_{4}$ emission [62,63]. Liu et al. [64] recorded 54\% higher seasonal methane emissions from conventional puddled transplanted rice fields than DSR rice, though $\mathrm{N}_{2} \mathrm{O}$ emissions were reduced by around $49 \%$ with puddled transplanted with $\mathrm{N}$ application. Chakraborty et al. [6] in a global data meta-analysis found that higher $\mathrm{CH}_{4}$ emissions under conventional puddled transplanting of rice compared to novel crop establishment practices while $\mathrm{N}_{2} \mathrm{O}$ emissions were unchanged. The reduced percolation by soil puddled layer under puddled transplanting of rice can increase methanogenesis by reducing the flow of oxygen-containing water [65] and hence emissions of $\mathrm{CH}_{4}$ to the atmosphere. Since $\mathrm{N}_{2} \mathrm{O}$ production from both nitrification and denitrification processes is sensitive to oxygen concentration, there are reasons to suspect that flooding (anaerobic condition) and draining (aerobic condition) of a soil will influence the $\mathrm{N}_{2} \mathrm{O}$ emissions. The rate of $\mathrm{N}_{2} \mathrm{O}$ emission from flooded paddy fields had been thought to be small [66]. However, denitrification can produce $\mathrm{N}_{2} \mathrm{O}$ from $\mathrm{NO}_{3}$ during drainage and/or during even drier soil conditions in anaerobic microsites [67]. The potential for high $\mathrm{N}_{2} \mathrm{O}$ flux is greater in wetland soils with high levels of $\mathrm{NO}_{3}{ }^{-}$and $\mathrm{NO}_{2}{ }^{-}$.

\subsubsection{Tradeoffs of Puddling on Yield and Economics}

The main consequence of puddling for rice establishment is that it degrades the soil physical conditions and results in lower yields of dryland crops in rice-based systems [31]. In addition, puddled transplanting of rice can delay the start of the next cropping season. For example, wheat yield declines by up to $1.5 \%$ for each day delay in wheat planting after the optimum sowing date [34].

The requirement of water, energy and labor, which are getting increasingly costly, are a threat to the profitability of puddled transplanting for rice and intensive tillage for subsequent wheat [68]. Mahajan et al. [69] added that the cost of traditional puddled transplanting of rice squeezed rice farming profitability mainly due to reduced available labor. Islam et al. [70] recorded the lowest BCR (1.42) in the puddled transplanting which they attributed to lower yield at the cost of increased inputs (fuel and machinery pass) and labor requirement for land preparation and seedling transplanting. Accordingly, conventional practice of rice planting is no longer able to sustain the productivity of rice cropping systems [10]. 


\subsection{Novel Crop Establishment Practices}

\subsubsection{General Background}

Successful cropping begins with good crop establishment. Farmers are increasingly convinced to grow upland crops according to CA (for example, zero tillage and strip tillage), but they persist with puddling of the soil for rice crop establishment [53]. Accordingly, whatever benefits that accrue by following CA for upland crops get destroyed by puddling for wetland rice crops. Over time, depending on farmer's willingness, agro-climates, demography and farm typologies, a number of rice establishment technologies has been developed to either save time, labor or cost for rice production or to enhance soil health according to CA principles [71-88].

\subsubsection{Direct Seeded Rice}

The direct-seeded rice area in Asia is estimated to be about 29 million ha (approx. 21\% of the total rice area). However, area coverage by direct-seeded rice appears to have decreased considerably in recent years [71]. Direct-seeded rice can be done after conventional tillage under wet or dry soil conditions. It can also be done in zero-tilled soil or with minimum tillage operations [6]. Direct seeded crops require less labor and tend to mature earlier than transplanted crops. Direct seeding avoids seedling stress from pulling roots from nursery-bed soil and the time taken to re-establish fine roots. Land preparation for direct seeding of rice is done in two ways:

\section{Dry Direct Seeding}

In rain-fed and submerged ecosystems, rice seeds are directly sown on to fields by broadcasting or drilling onto surface soils which are then covered or incorporated in soils by ploughing or harrowing (A detail description can be found in http://www.knowledgebank.irri.org/step-by-step-production/ growth/planting/direct-seeding\#dry-direct-seeding). In Asia, dry seeding which is followed in flood-prone areas, rainfed lands, lowlands and uplands [72,73]. In rice growing areas of India, Vietnam, the Philippines, Malaysia, Thailand, DSR is rapidly being accepted for rice crop establishment [74].

\section{Wet Direct Seeding}

In wet fields under irrigated and deep-water conditions, direct seeding can be performed either through broadcasting or drilling seeds into the wet or moist soil with a seeder.

According to Rao et al. [75], direct-seeded rice crop establishment covered $23 \%$ of rice establishment in 2007. In the highly mechanized agricultural systems, as in the United States, Australia and Europe, either water-seeded or dry seeded or both water-seeded and dry-seeded system are used to establish rice crops [76,77]. Farmers in Chile, Cuba, southern Brazil, Venezuela, some Caribbean countries and some areas of Colombia have adopted direct seeding on saturated soil [78].

\subsubsection{Water Seeding}

The water seeding technique for rice establishment in California (United States), Australia, Malaysia and European countries controls the growth of weeds which are difficult to eradicate. When pre-germinated seeds are broadcasted on puddled soil, it is called wet water seeding and when broadcasted on non-puddled soil it is called dry-water-seeding $[79,80]$. In addition to irrigated areas, water seeding helps farmers to cope with growing rice in fields with early flood water which cannot be drained out quickly. In the highly mechanized rice planting systems, water seeding is the principal means of crop establishment [74,75]. For example, Australia has most rice planted aerially in water [75]. Water-seeding is also common practice in some states of the USA $[79,80]$. 


\subsubsection{System of Rice Intensification (SRI)}

The System of Rice Intensification (SRI) is a package of distinctive practices affecting seedling transplanting, water management, weed control along with increased use of organic nutrients $[81,82]$. The SRI consists of transplanting young, 8-12 day-old seedlings, single seedling transplanting (one per hill) in a square pattern of $25 \times 25 \mathrm{~cm}$, transplanting seedlings within 15-30 min after removal from the nursery and at shallow depth (at 1-2 cm deep), keeping paddy soil moist but not continuously saturated, controlling weeds with frequent weeding by a mechanical hand weeder and applying organic fertilizers with chemical fertilizers. The puddled paddy soil is kept moist but not consistently saturated so that mainly aerobic soil conditions prevail. Weeding is frequently done to facilitate aeration of the soil [83]. Irrespective of the debate on the claims of the practice, the SRI practice has been disseminated worldwide [84]. SRI-Rice [85], FAO [86] and World Bank [87] reported that more than 10 million farmers of more than 50 countries of Asia, Africa and Latin America adopted and derived benefit from the use of SRI methodology since 2000.

\subsubsection{Non-Puddled Transplanting of Rice}

Several minimum soil disturbing options could be used to establish rice by non-puddled transplanting: Single-pass shallow tillage (SPST); strip tillage and bed formation [28]. The SPST method involves full surface soil disturbance to $4-6 \mathrm{~cm}$ depth and full residue incorporation by tillage. Hence it reduces the number of tillage operations and depth of tillage compared to conventional puddling but does not apply the principles of CA, namely minimum soil disturbance and crop residue retention. Nevertheless, the shallow soil tillage may be sufficient for weed control before non-puddled transplanting of rice seedlings [88]. Strip tillage involves disturbance of a zone $4-6 \mathrm{~cm}$ wide and up to $6 \mathrm{~cm}$ deep, covering approximately $15-25 \%$ of the soil surface. Hence this can be considered as a form of minimum soil disturbance which together with more than $30 \%$ of residue retention falls within CA guidelines. Rice seedlings are transplanted into the disturbed strips which are soaked with water overnight to soften the soil. Narrow strips on the top of permanent raised beds are also used for non-puddled transplanting of seedlings after wetting up the soil $[7,19]$.

Bell et al. [2] reported that around 2.5\% of farmers in areas in Bangladesh that had been exposed to the technologies had taken up non-puddled transplanting of rice (NP of rice). Moreover, it was reported in 2017 that the NP of rice with and without mechanization was gaining momentum in the EGP area $[89,90]$.

To alleviate scarcity of agricultural laborers, mechanized transplanting of rice seedlings under zero tilled conditions, in non-puddled soil and in puddled soil condition is increasingly done by self-propelled transplanter. Increased productivity of crops, energy and water, and savings of labor when rice is established by mechanical transplanting technology have been reported [91,92]. However, there are challenges of making this service available to farmers commercially at large scale. Sudhir-Yadav et al. [93] reported that the technology still faces challenges due to lack of testing widely on farmers' fields, farmers' unwillingness and inability to invest in the high initial cost of the machine, unavailability of the machines, lack of skilled service providers and troubleshooters, lack of seedling nursery (mat-type) raising skills, and unsatisfactory performance of the machine in lowland monsoon ecology.

\subsubsection{Drip Irrigation under Different Rice Establishment Practices}

Irrigated rice on 15-20 mill. ha in Asia is predicted to suffer paucity of water availability. Under these circumstances, research has been done in the main rice growing areas in Asia to evaluate drip irrigation under different crop establishment practices. Rao et al. [94], for example, reported that SRI techniques with drip irrigation (emitters spaced at $40 \mathrm{~cm})$ performed the best in terms of yield, water productivity $(0.90 \mathrm{~kg}$ $\mathrm{m}^{-3}$ ) and water energy productivity. In another study, Bansal et al. [95] also reported similar results in their experiments with on-farm drip irrigation in rice at Haryana, India. Parthasarathi et al. [96] also reported increased aerobic rice yield and water savings by 29 and 50\%, respectively at Coimbatore, India using 
drip irrigation. Water productivity of aerobic rice under the drip irrigation system of rice was increased by $200 \%$. Jat et al. [97] conducted experiments on drip irrigation in the rice-wheat system in North-West India. They demonstrated that rice-wheat system which employed conventional tillage required $1889 \mathrm{~mm}$ irrigation water ha-1 in contrast with CA with drip irrigation system that required $882 \mathrm{~mm}$ irrigation water $\mathrm{ha}^{-1}$. The CA with drip irrigation also recorded $11.2 \%$ higher crop productivity and $29 \%$ higher profitability relative to current practice of farmers.

\subsubsection{Conclusions}

The varied crop establishment practices for rice are likely to differ in performance among soil types, agro-climatic zones, management approaches for water and weeds, type of tillage machinery available and cropping intensity. Besides, based on the farmers' skills, and willingness to adopt technology, the performance of the crop establishment practices also vary. However, information on appropriateness of the establishment technology for different rice based systems is still limited.

\section{Tradeoffs of Novel Rice Crop Establishment Practices on Soil Properties}

Conventional cultivation practices involving repeated wet tillage operations are detrimental to soil physical, chemical and biological properties and can lead to a reduction of the yield of post-rice crops [36]. The CA approach by contrast involving minimum soil disturbance, crop residue retention, and appropriate crop rotations has been associated with improving soil health, reduction of soil erosion [98] decrease in consumption of fossil fuels [99] and decreased cost of crop production [100].

Repeated tillage develops a hardpan under/at the bottom of the plough layer which impedes water infiltration which is beneficial for water retention in the root zone for wetland rice. However, for the non-rice crops grown in rotation with rice, root growth is inhibited leading to poor crop performance (depends on soil type) [100]. Moreover, soil structure is damaged by destructive tillage which disrupts soil aggregates, reduces available soil water holding capacity as well as accelerating organic matter depletion [101] which hampers soil functions and crop yield in the long run [75,102]. The return of residue can minimize the SOM decline $[103,104]$. The alternative crop establishment techniques have varied effects on soils properties and these are reviewed below.

\subsection{Tradeoffs on Soil Physical Properties}

Soil physical properties deterioration by inappropriate crop establishment practice has many implications on soil fertility, yield of crops and GHG emission from rice-based cropping systems [105]. The potentials of CA to eradicate the soil physical constraints for establishment of rice and the subsequent crops are evaluated in many studies [23,33]. The most conspicuous effect of omission of puddling is the change in aggregate size distribution in the upper soil layer. Adoption of non-puddled based crop establishment practices increased aggregation index and mean weight diameter of aggregates in soils relative to those in the puddled soils in both $0-15$ and $15-30 \mathrm{~cm}$ layers [106]. Rice transplanting with the use of non-puddling or by direct seeding conserved or increased macroaggregates in soils [106-108]. In addition to less disturbance of soils, retention of low quality residue can stabilize aggregates in non-puddled soils [109]. In terms of water holding capacity (WHC) of soils under rice-based cropping systems, the ZT in upland crops and non-puddling required less water for rice crop establishment and conserved higher moisture in soils for dry season crops $[7,23,33,106]$ which Mondal [106] attributed to better aggregation and increased accumulation of SOM [7]. Besides, increased WHC in soils under non-puddled rice indicated increased medium size pore development which has more storage capacity of soil moisture. In a seven year study of the IGP, Gathala et al. [107] employed DSR on flat and raised beds followed by ZT wheat to compare with puddled transplanting of rice followed by CT wheat. They recorded the lowest BD $\left(1.66-1.71 \mathrm{~g} \mathrm{~cm}^{-3}\right)$ and soil penetration resistance $(3.46-3.72 \mathrm{MPa}$ at $20 \mathrm{~cm}$ depth) under ZT based DSR treatments. The infiltration rate was higher in the CA based practice of rice establishment $\left(0.29-0.40 \mathrm{~cm} \mathrm{~h}^{-1}\right)$ compared with conventional practice $\left(0.18 \mathrm{~cm} \mathrm{~h}^{-1}\right)$ [107]. More details of soil physical manipulations by different crop establishment practices are given in Table 1. 


\subsection{Tradeoffs on Chemical Properties (Other Than N)}

In rice-based cropping systems, Nandan et al. [108] conducted field experiments on rice-wheat and rice-maize cropping systems for six years to evaluate the effects of different crop establishment practices on soil properties. The tillage practices were puddled transplanting of rice followed by conventional tillage in wheat/maize; NP of rice followed by ZT in wheat/maize; ZT transplanted rice followed by ZT in wheat/maize; ZT DSR followed by ZT in wheat/maize. The residue removal practice was contrasted with residue retention $(\sim 33 \%)$ under the crop establishment practices. After six years of rotation, they reported that soil $\mathrm{pH}$ and electrical conductivity were unaffected by establishment practices of crops and retention of residues and cropping systems, but $\mathrm{pH}$ was significantly higher in soils under residue removal treatment. In another example, Kumar and Yadav [109] conducted an experiment on the effect of tillage on the productivity of wheat after rice during winter seasons (1997-98 and 1998-99) at Faizabad, Uttar Pradesh, India and found a slight decrease in the soil pH under CT. However, the incorporation of crop residues/plant matter in soil by tillage may significantly increase soil $\mathrm{pH}$ [110]. Mandal et al. [111] stated that the high content of siliceous material in rice crop residues can transform the electrochemical properties of acid soils by reducing soil $\mathrm{pH}$, diminishing $\mathrm{P}$ fixation, and improving base retention. In a long-term study conducted on loamy sand at Ludhiana, India by Balwinder-Kumar et al. [112] integrated nutrient management which includes farmyard manure (FYM), green manure and crop residues in the rice-wheat system decreased soil $\mathrm{pH}$ after 8 cycles of rice-wheat system marginally.

The response of immobile nutrients ( $\mathrm{P}$ and $\mathrm{K}$ ) in soils to crop establishment practices following CA practices (by NT, ZT or strip tillage with residue retention) are different from N. Firstly, accumulation of $\mathrm{P}$ and $\mathrm{K}$ in the surface soils (at $0-5$ or $0-10 \mathrm{~cm}$ soil depth) $[113,114]$ is common in CA practices, while below the surface layer the levels are similar to CT practice of crop establishment $[113,114]$. Selles et al. [115] conducted an experiment on ZT and reported that $P$ was accumulated in the surface soil due to the absence of soil disturbance. The stratification of $\mathrm{P}$ in the topsoil under ZT compared with CT is also commonly found in non-rice cropping systems [116].

In an 11-year field experiment on a loamy sand soil in Punjab, India, Beri et al. [117] showed that the residue incorporation of crops in the rice-wheat cropping system increased the available $\mathrm{P}$ in soil over the crop residue removal practice. Available $\mathrm{P}$ in soil was in the order: residue incorporation $>$ residue removal $>$ residue burning. Misra et al. [118] recorded increased $p$ in available form after long-term crop residue incorporation in the rice-wheat rotation in the Eastern IGP, India [118].

Pierce et al. [119] and Redel et al. [120] conducted a trial on ZT and CT with crop residue retention and found that $Z \mathrm{~T}$ and crop residues together increased available $\mathrm{P}$ of the surface soil. They attributed the accumulation of soil extractable $\mathrm{P}$ to broadcasting of $\mathrm{P}$ containing fertilizer and retention of increased amount of crop residues on the surface of soil [121]. On the other hand, Pradhan et al. [122] revealed that soil extractable $\mathrm{P}$ increased significantly due to retention of crop residue in both ZT and CT practices. In a tillage experiment, direct drilling accumulated preferentially increased available $\mathrm{P}$ in the surface layer of acid soil, compared with farmers' mechanical cultivation practice. However, the crop grown by direct drilling required increased $P$ fertilizer application compared with conventional tillage because crops under the direct drilling practice had lower uptake of soil $\mathrm{P}$, leading to yield reduction [123]. Soil disturbance levels also regulate chemical nature of $\mathrm{P}$ in soils, while CA practice and higher activity of microbes during SOM decomposition are attributed to increased P solubility [124]. Ohno and Erich [125] stated that standing crop residue retention or retention of residues on the soil as mulch increase soil $\mathrm{P}$ availability by reducing P adsorption to surfaces of soil minerals which complements biologically mediated release of organically-bound P to improve crop P status.

Numerous researchers, e.g., [126,127], reported surface stratification of $\mathrm{K}$ in minimum disturbance of soil (especially in ZT) compared to CT, because of K-bearing fertilizers and crop residue application on the soil surface, accompanied by lack of soil disturbance. Franzluebbers et al. [128] reported increased K content in soil due to plant residues retention. However, Tony and Janovick [129] reported that long-term minimum tillage required higher amount of $\mathrm{K}$ application to maintain $\mathrm{K}$ supplying capacity in subsurface layer, because of its immobile nature together with its accumulation in the surface layer. When soil is rich 
in $\mathrm{K}$ or adequate amounts of $\mathrm{K}$ fertilizer were previously applied to the calcareous soils, extractable $\mathrm{K}$ was not affected by disturbance of soil (tillage) and residue management [130].

In dry areas and in sandy soils, stratification of immobile nutrients close to the soil surface under minimal disturbance of soil (ZT practices) and shallow nutrient placement could render nutrients unavailable due to moisture scarcity. Hence, in such soils, deficiency of $\mathrm{P}$ and $\mathrm{K}$ for crop growth is likely if there is low extractable $P$ in the subsoil or root growth is constrained by physical or chemical constraints. Deep banding of less-mobile nutrients may be useful in those studies [131,132]. While Alam et al. [133] did not find any significant benefit for crop growth, root distribution, and yield of maize following deep banding of $\mathrm{P}$ under minimum disturbance of soil, further research should be conducted in other soils and climates to see how ZT under surface banding of $P$ improves $P$ acquisition by crops and increase yield of crops. It would also be worthwhile to determine how modifying root activities [134] under ZT practice and surface banding P placement alters uptake of other nutrients. The increasing adoption of CA by the growers in rice-based cropping systems increase the need to manage crop availability of the less mobile nutrients ( $\mathrm{P}$ and $\mathrm{K}$ ) due to reduced mixing of fertilizers in the root zone, reduced mineralization of organic matter $(\mathrm{OM})$, and greater nutrient stratification close to the soil surface.

Rahman [135] in a field experiment at Mymensingh, Bangladesh to study the release pattern of nutrients and the effect of crop residues and tillage practices on $S$ availability. The available $S$ followed a sequence: MT with crop residues $>$ CT with crop residues $>$ CT without crop residues $>$ MT without crop residues. On the other hand, Yadvinder-Singh et al. [136] found that residue incorporation into the soil reduced losses of $S$ by leaching and maintained $S$ fertility of soils since crop residues contained appreciable quantities of $S$. Nevertheless, incorporation of crop residues by tillage may have short-term beneficial effects on soil available $S$, because tillage and residue decomposition leads to accelerated S mineralization [113].

Alam et al. [16] found that after four years of different tillage practices the TN content, available P content, available K content and available S content in ZT was 32, 37, 35 and 31\% higher than CT, respectively, in a wheat-mung bean-rice cropping system. In line with this, Salahin [25] recorded that minimum tillage practices (ZT and ST) increased SOC, TN and extractable P, S and Zn contents in the upper $0-5 \mathrm{~cm}$ soil layer in lentil-jute-rice cropping system after three years of study.

Table 1 summarises findings about the effects of different rice establishment practices on soil characteristics.

Table 1. Effect of rice crop establishment practices on soil properties.

\begin{tabular}{|c|c|c|c|}
\hline Source & Practices Adopted & Soil Type & Results \\
\hline Alam et al. [16] & $\begin{array}{c}\text { Zero tillage (ZT), } \\
\text { minimum tillage }(\mathrm{MT}), \\
\text { conventional tillage }(\mathrm{CT}), \\
\text { and deep tillage (DT) } \\
\text { with residue retention at } \\
\text { the rate of } 30 \% .\end{array}$ & Clay loam & $\begin{array}{l}\mathrm{ZT} \text { and MT with mung bean biomass and } \\
\text { residue incorporation conserved moisture } \\
\text { in the soil profile, reduced the bulk density } \\
\text { (BD), and increased OM, porosity, available } \\
\text { water content and root mass density. } \\
\text { ZT and MT practices increased soil organic } \\
\text { carbon, TN, P, K and S in their available } \\
\text { forms in soils. }\end{array}$ \\
\hline Alam et al. [7] & $\begin{array}{l}\mathrm{ZT}, \mathrm{CT} \text { and DT and } \\
\text { wheat-fallow-T. } \\
\text { Aman, wheat-mung } \\
\text { bean-T. Aman and } \\
\text { wheat-dhaincha-T. } \\
\text { Aman rotations }\end{array}$ & Clay loam & $\begin{array}{l}\text { Minimum soil disturbance together with } \\
\text { the incorporation of a legume/green manure } \\
\text { crop into the rice-wheat system as well as } \\
\text { the retention of their residues increased soil } \\
\text { C status, improved soil properties (BD, } \\
\text { porosity, field capacity, plant available } \\
\text { water content), increased root mass density } \\
\text { and maximized grain yields. }\end{array}$ \\
\hline Mondal et al. [106] & $\begin{array}{l}\text { Puddled transplanted, } \\
\text { puddled transplanted } \\
\text { with System of Rice } \\
\text { Intensification (SRI), } \\
\text { non-puddled } \\
\text { transplanted, } \\
\text { non-puddled } \\
\text { direct-seeded }\end{array}$ & Loam & $\begin{array}{l}\text { Omission of puddling and absence of soil } \\
\text { disturbance improved BD, penetration } \\
\text { resistance (PR), aggregate stability, cracking } \\
\text { behaviour, soil organic carbon (SOC) and } \\
\text { soil nutrient status. }\end{array}$ \\
\hline
\end{tabular}


Table 1. Cont.

\begin{tabular}{|c|c|c|c|}
\hline Source & Practices Adopted & Soil Type & Results \\
\hline Mohanty et al. [137] & $\begin{array}{l}\text { No puddling; puddling } \\
\text { with four passes of a } \\
\text { rotary tiller and } \\
\text { transplanting; puddling } \\
\text { with eight passes of a } \\
\text { rotary tiller and } \\
\text { transplanting with } \\
\text { residue retained and } \\
\text { residue removed }\end{array}$ & Clay & $\begin{array}{l}\text { Omission of puddling improved BD, PR, } \\
\text { water stable aggregates (WSA) and SOM }\end{array}$ \\
\hline Bajpai and Tripathi [138] & $\begin{array}{c}\text { For rice, puddling }(\mathrm{P}) \text { for } \\
\text { transplanted rice and } \\
\text { non-puddling for direct } \\
\text { drilled rice and two } \\
\text { fertility levels: (NPK) } \\
\text { 120:40:40 kg ha }{ }^{-1} \text { and } \\
\text { 180:60:60 kg ha }{ }^{-1} \text {. } \\
\text { For wheat, the CT and } \\
\text { ZT and the two fertility } \\
\text { levels }\end{array}$ & Silty clay loam & $\begin{array}{l}\text { Puddling significantly decreased the BD of } \\
\text { the surface soil at the tillering stage of rice, } \\
\text { compared to non-puddling, whereas it was } \\
\text { significantly higher after harvest. } \\
\text { The hydraulic conductivity of the } 0-0.06 \mathrm{~m} \\
\text { soil depth also reduced to one-sixth and } \\
\text { one-half due to puddling at tillering and } \\
\text { harvesting stages, respectively. } \\
\text { Infiltration rate was decreased from } 0.68 \text { to } \\
0.46 \mathrm{~mm} \mathrm{~h}^{-1} \text { at tillering and } 1.78 \text { to } 0.94 \mathrm{~mm} \\
\mathrm{~h}^{-1} \text { at harvest due to puddling. } \\
\text { The puddling only in rice enhanced the root } \\
\text { length density by } 12 \% \text { but affected the } \\
\text { wheat crop adversely and minimised the } \\
\text { root length density by } 28 \% \text {. Both puddling } \\
\text { and non-puddling were found to be equally } \\
\text { effective for grain yield of rice. } \\
\text { However, NP of rice produced significantly } \\
\text { higher wheat grain yield than that of wheat } \\
\text { followed by puddled rice. }\end{array}$ \\
\hline Mousavi et al. [139] & $\begin{array}{l}\text { Four levels of puddling } \\
\text { intensity used: No } \\
\text { puddling, low puddling, } \\
\text { medium puddling and } \\
\text { high puddling. The first } \\
\text { tillage performed with a } \\
\text { moldboard plough and } \\
\text { then the plots were } \\
\text { puddled using a rotary } \\
\text { tiller. }\end{array}$ & Silty clay soil & $\begin{array}{c}\text { Increasing puddling intensity increased the } \\
\text { BD linearly. Increasing puddling intensity } \\
\text { decreased water percolation. } \\
\text { Puddling increased the amount of water } \\
\text { retained over the whole range of matric } \\
\text { potentials. Non-puddled plots required } \\
\text { significantly lower water for crop } \\
\text { establishment. }\end{array}$ \\
\hline Alam et al. [7] & $\begin{array}{l}\text { Conventional puddling } \\
\text { and non-puddling } \\
\text { following strip planting } \\
\text { with low and increased } \\
\text { residue retention }\end{array}$ & Silt loam & $\begin{array}{l}\text { Soil BD decreased under non-puddled } \\
\text { transplanting after } 4 \text { years of rice-based } \\
\text { paddy-upland rotations. }\end{array}$ \\
\hline Islam [23] & $\begin{array}{l}\text { Strip planting and bed } \\
\text { planting for upland } \\
\text { crops and conventional } \\
\text { puddling and } \\
\text { non-puddling following } \\
\text { strip planting with low } \\
\text { and increased residue } \\
\text { retention for rice }\end{array}$ & Silt loam & $\begin{array}{l}\text { Implementation of strip planting and bed } \\
\text { planting for upland crops and non-puddled } \\
\text { transplanting for rice gradually improved } \\
\text { soil physical properties and alleviated } \\
\text { puddling effects that characterise current } \\
\text { practices (CT and low residue retention } \\
(\mathrm{LR})) \text { in rice-based systems. }\end{array}$ \\
\hline Salahin [33] & $\begin{array}{l}\text { Zero tillage and strip } \\
\text { tillage under the } \\
\text { non-puddled condition, } \\
\text { bed planting (BP) and } \\
\text { conventional puddling } \\
\text { with } 20 \% \text { and } 50 \% \\
\text { residue retention }\end{array}$ & Sandy loam & $\begin{array}{l}\text { Soil BD significantly changed due to } \\
\text { different tillage practices after three crop } \\
\text { cycles. ZT and non-puddling transplanting } \\
\text { with increased crop residue retention (50\%) } \\
\text { had a positive effect on soil PR and soil } \\
\text { moisture content. The non-puddling } \\
\text { transplanting plots conserved more soil } \\
\text { moisture with the least PR values compared } \\
\text { to the other tillage practices. }\end{array}$ \\
\hline
\end{tabular}


Among the research gaps identified are the effects of SRI-based rice cropping on soil properties. Rice crops grown under SRI practices experienced soil drainage at the vegetative development phase which has implications for the use of organic fertilizers [81,140].

By applying NP transplanting of rice or DSR under dry condition, the water requirement for irrigated rice establishment is decreased [141]. However, when CA practices are followed over several years, the plough pan may start to disappear, which may increase deep drainage of monsoon rainwater or irrigation water. While deep drainage of water to the groundwater is not a loss, pumping irrigation water is costly and if there is an increased requirement that will decrease profitability of rice crops. On the other hand, where there is significant runoff loss of rainwater, increased deep drainage may boost the storage of water in groundwater or replenish depleted groundwater reserves [142,143]. There is still a lack of detailed studies on net water requirement and water balance under different crop establishment methods [92] There may also be negative effects of increased deep drainage on nutrient balance in rice-based cropping systems.

\subsection{Tradeoffs on SOC and Total $N$}

There are relatively few studies that report the effects of establishment method on SOC and total $\mathrm{N}$. As native soil $\mathrm{N}$ mineralization provides $20-80 \%$ of the $\mathrm{N}$ required by plants [144], the management of crop residues during rice establishment has an important role in soil $\mathrm{N}$ supply to crops and subsequently on plant growth [145]. Rapid mineralization of SOM and potential loss of C and N from the soil occur in the traditional crop establishment practice (puddling followed by soil tillage) during the initial stage of rice growth [146]. Distinct rise in $\mathrm{N}$ mineralization was observed 3-5 days after incorporation of residues by conventional tillage and puddling, as SOM within the macro-aggregates became more available to microbes and oxidation increased over time [147]. In a study by Zhou et al. [22] with conventional rice establishment, it was concluded that $\mathrm{N}$ cycling in paddy-upland rotation reduced soil $\mathrm{N}$ storage due to excessive water application, disturbance of soil and removal of residues from field or by burning.

In general, $\mathrm{ZT} /$ minimum soil disturbances along with residue retention and incorporation of leguminous crops between cereal crops increases topsoil SOM accumulation in a wide range of soils worldwide [16,20]. Bell et al. [20] estimated an additional 131-145 million t $\mathrm{CO}_{2}$ eq of $\mathrm{C} \mathrm{ha}{ }^{-1}$ could be sequestered in the rice-based cropland of the EGP based on results of a 4-5-year experiment (at Alipur and Digram, Bangladesh) implementing NP of rice followed by strip planting (SP) in place of conventional cropping. Zero tillage (ZT) rice and $\mathrm{ZT}$ wheat with residue retention in permanent raised beds increased the soil organic carbon (SOC) contents in the $0-10 \mathrm{~cm}$ depth sequestering the equivalent of 103 million $\mathrm{t} \mathrm{CO}_{2}$ eq ha ${ }^{-1}$ and 87 million $\mathrm{tCO}_{2}$ eq ha ${ }^{-1}$, respectively, after seven years in EGP [148]. Addition of crop residues under minimum disturbance practice protects soils from erosion and crust formation [78]. Since crop residues remain at the soil surface under minimum tillage practices [149] they are less accessible to microbial breakdown [150] which facilitates C and N accumulation in soil $[20,23,33]$. Moreover, the retained crop residues with minimum disturbance of soil help lower evaporation loss of water and regulate thermal properties in a more favorable range for crop production [151].

Alam et al. [42,52] conducted $\mathrm{C}$ and $\mathrm{N}$ cycling studies in two rice-based cropping systems (mustard-irrigated rice-monsoon rice and wheat-jute-monsoon rice) in the EGP and reported that SP, including NP of rice seedlings, together with increased residue retention (HR) increased SOC by 0.35 and $0.23 \%$ relative to current farm practice and conventional practices (CT) with HR, respectively. The same practices increased total $\mathrm{N}$ by 0.021 and $0.032 \%$ relative to current farm practice and $\mathrm{CT}$ with $\mathrm{HR}$, respectively. The long-term practice of NP with minimal residue retention $(20 \%)$ increased $\mathrm{C}$ and $\mathrm{N}$ accumulation above that of the current farm practice. In addition, $\mathrm{SP}$, and NP of rice, together with $\mathrm{HR}$ alter $\mathrm{N}$ cycling by increasing the mineral $\mathrm{N}$ available to plants during the period of peak crop $\mathrm{N}$ demand and by increasing soil $\mathrm{N}$ level [42]. 
Nandan et al. [108] reported a significantly higher proportion of macro-aggregates (water-stable), the macro-aggregate: micro-aggregate ratio and aggregate-associated C in zero-tillage DSR and NP of rice over CT puddling practice. However, equivalent studies on strip-till NP of rice and SP for upland crops are lacking to compare with other crop establishment practices. Nandan et al. [75] also concluded that the effect of crop establishment practices in rice-based cropping system have not adequately addressed the effect on classes of soil aggregates, their associated $C$ and other nutrients and their stability.

The weakening of the plough layer in paddy fields after long-term CA practices in rice-based cropping may induce greater deep drainage of water. The implications of this change for $\mathrm{C}$ and $\mathrm{N}$ dynamics and losses to ground water have not been investigated.

\subsection{Tradeoffs of Crop Establishment Practices on Soil Biological Properties}

\subsubsection{On Microbial Biomass, Microbial Biomass Carbon and Nitrogen}

Microbial biomass in soil (SMB) works as an active fraction of SOM. With rapid response to management practices, $\mathrm{SMB}$ is critical for $\mathrm{C}$ and $\mathrm{N}$ cycling in the agro-ecosystems and maintenance of soil fertility. Management practices influence soil biological properties (microbial biomass, microbiome community and structure, microbiome taxonomy, abundance and activity) by altering the physical and chemical properties of soil [152]. Zhang et al. [153] reported that the level of soil disturbance and retention of crop residue controls accumulation of microbial biomass. In a rice-based crop rotation (rice-barley rotation) under tropical dryland agroecosystem, Kushwaha et al. [154] found that modification of tillage (minimum and ZT) and retention of residue increased the SOC and TN in SOM as SMB. In a farmers' participatory study in Karnal, India, Choudhary et al. [155] evaluated effects of soil disturbance, cropping systems, crop establishment method and residue retention on soil microbial biomass C (MBC) and microbial biomass $\mathrm{N}$ (MBN). Maize-wheat system with ZT and residue retention registered 208 and 263\% improvement in soil MBC and MBN, whereas rice-wheat system with ZT and residue retention registered 83 and $81 \%$ increases, respectively, as compared with rice-wheat system under $\mathrm{CT}$ without residue retention (conventional practice). Wang et al. [156] stated that CA system favored increased levels of MBC and MBN, when compared to CT. They attributed the increased $\mathrm{MBC}$ and $\mathrm{MBN}$ to reduced tillage, increased $\mathrm{C}$ inputs, and retention of residues.

Cropping systems affected MBC and MBN as multi crops cropping systems had higher amount of MBC and MBN, when compared to single- or double-crop rotations [7,157]. Even under deep tillage system, Alam et al. [7] recorded increased MBC (14 and 6\% over initial values) under wheat-dhaincha-rice and wheat-mung bean-rice cropping systems, while a negative result (relative to conventional tillage) was recorded in deep soil tillage under fallow in between wheat and rice cropping system. Other studies that employed chisel plough and ZT supported the result by recording an increase of MBC (over CT by 57 and 181\%, respectively) [158]. Zero tillage and minimal disturbance of soil with residues from rice and wheat in wheat-dhaincha-rice system enhanced accumulation of MBC $[159,160]$. The authors attributed the MBC increase in soil to favorable conditions created by $\mathrm{ZT} /$ minimal disturbance of soils and residue retention in soil over time. In the sub-tropical conditions, Balota et al. [161] recorded an increase of MBC in ZT over DT and CT which they attributed to higher soil aggregation, lower temperature, greater soil moisture content, and higher SOC content. Balota et al. [161], and Alam et al. [7] also added that the ZT/minimal disturbance of soils allowed a stable source of SOC to accumulate which supports the microbial community, while OC in deep tillage or CT underwent a flush of microbial activity and thereby enhanced losses of $\mathrm{C}$ as $\mathrm{CO}_{2}$. Alam et al. [52,162] conducted experiments on modification of reduced tillage practices (i.e., strip tillage and bed planting) in combination with increased residue retention in rice-based cropping systems (mustard-irrigated rice-monsoon rice and wheat-jute-monsoon rice). They compared these practices with CT practices with low residue retention in the EGP. They recorded higher MBC under the modified tillage practices and increased residue retention than under $\mathrm{CT}$ and low residue retention. The higher MBC values 
in soils under strip tillage and bed planting with increased residue retention might be attributed to reduced soil disturbance required to establish three crops per year. In addition, greater crop or biomass productivity under tillage practices together with increased residue retention supplied more total carbon for the increased MBC levels in the soils [163].

\subsubsection{On Enzyme Activities}

Soil enzyme activity has been found to be higher with CA management practices than with the traditional practices [155]. In CA, residue addition, minimal soil disturbance, and rotating crops play an important role in increasing enzyme activities in soil. Bandick and Dick [164] identified CA practices with significantly higher enzyme activities due to previous crop roots, compared to CT practices. With crop residue retained on the surface of soil, CA practices have higher soil moisture retention capacity and plant available water than CT practices which, in the end, influences the enzyme activities under CA practices [165]. Wang et al. [166] recorded increased total soil $P$ and phosphatases activity under no-till with residue retention on the soil surface which they attributed to the supply of readily available substrates (carbohydrates) to microorganisms. In another study, Rolden et al. [167] found decreased dehydrogenase activity under intensive tillage practices. $\beta$-glucosidase enzyme is associated with microbial degradation of cellulose to glucose [168] which Choudhary et al. [155] found was higher in soils of CA based rice-wheat cereal systems compared to conventional farm practices. Choudhary et al. [155] also reported 210 and $48 \%$ increase in activities of dehydrogenase and alkaline phosphatase in soils under maize-wheat system with ZT and residue retention, whereas rice-wheat system with ZT and residue retention had 44 and 13\% higher activities, respectively as compared with CT without residue retention.

\subsubsection{On Microbial Community and Diversity}

Apart from enzyme activities and microbial biomass, microbial diversity is affected by crop management practices [160]. Tillage systems (CT or CA systems) could make a significant difference in the soil microbial community structure, diversity and predicted function $[155,169,170]$. Smith et al. [170] showed that soils under no-tillage systems accommodate bacterial microorganisms in higher numbers which carry genes responsible for degradation of protein, assimilation of ammonia and denitrification, while soils under CT systems support increased bacterial populations that carry genes responsible for production of nitrous oxide and ammonification. Again, diversified crops in cropping systems have diverse root exudates and produce crop residues varied in qualities which upon retention in the soil affect microbial structure (diversity, density) and growth [171].

In a farmer's participatory research trial in Karnal, India, Choudhary et al. [155] recorded the highest microbial population (e.g., bacteria, fungi and actinomycetes) in the maize-wheat system under ZT and residue retention. With continuous retention of crop residues on the soil surface, Choudhary et al. [155] recorded greater microbial diversity under management practices in line with full CA. They attributed the higher diversity to favourable fungal growth and activities, and their broad hyphal networks established and maintained by the full CA-based ZT systems. Bailey et al. [172] reported that CA based ZT system was responsible for a shift towards fungal-dominated microbial communities. The ZT system created the communities in closest similarities to natural ecosystems and played an important role for decomposition of residues and processes of nutrient cycling. In the study of Choudhary et al. [155], Ascomycota and Basidiomycota fungi were the dominant phylum in all the four management practices. With no tillage system, a similar result on Ascomycota and Basidiomycota fungal dominance was reported by Miura et al. [173]. The wheat-mungbean-maize system under ZT practice (fully CA-based) kept increased crop residues on soil surface and resulted in the highest (74\%) Ascomycota abundance as these fungi group is mainly responsible for residue degradation. Moreover, the abundance/dominance of Ascomycota fungi is influenced by residue quality (substrate) which are recorded different in a wheat-mungbean-maize system under ZT practice (fully CA-based) from other studied rice-based systems and management practices. Wang et al. [174] recorded similar 
results of Ascomycota dominance in their study. In line with [155,174], Phosri et al. [175] stated that, because of having cellulolytic enzymes production potential, soils under increased residue retention practice have Sordariomycetes fungi in abundance. On the other hand, Maarastawi et al. [176] stated that growing rice in rotation with other crops helps grow diversified microorganisms in the rhizosphere as different crops grow in different soil moisture regimes. Growing rice in rice-legume rotation favours colonisation of the species of Herbaspirillum, and Bradyrhizobium, for example, in the interior of rice roots, which may enhance the growth and productivity of rice crop [177]. Apart from fungal diversity, Ceja-Navarro et al. [178] reported a higher levels of bacterial abundance and diversity in soils under no-till compared to CT practice. Sun et al. [179] also echoed the results of [178] which stated very low bacterial abundance in soils under CT system.

Any novel cropping practices such as CA practices could grow a different set of diversified rhizosphere microorganisms if the practices are continued for a considerable long-time. Research on the effect of the novel rice establishment practices (ZT, ST, BP, DSR (dry or wet), SRI and NP), crop residue retention and crop rotation practices on soil microorganisms, and related biological activities and processes in soils warrants further in-depth research. This should focus on resolving the long term contributions of minimal disturbance of soils, residue retention and growing diversified crops in crop rotations on soil biological properties that improve the soil fertility and productivity.

\section{Carbon Cycle of Rice-Based Cropping Systems}

The $C$ storage in soils is determined by the inputs such leaf and root litter and the losses from decomposition and mineralization processes (heterotrophic respiration). Root systems make a significant contribution to $C$ inputs and it is estimated that $50 \%$ of $C$ fixed in photosynthesis is transferred below ground to SOM [180]. Wetland rice requires anaerobic soil conditions that are different from those required by crops grown in upland conditions $[16,22,139,181]$. The wetting and drying in rotation accelerate or retard $\mathrm{C}$ and $\mathrm{N}$ dynamics. Paddy-upland rotation fields also experience seasonal alternation of wetting and drying and the frequent alternation between anaerobic and aerobic conditions [22], while the chemical speciation and biological effectiveness of soil nutrient elements vary with these conditions [22,182]. In a double- or triple-crop rice system, fallow periods are short so that the soil may not fully dry and re-oxidize completely, and large amounts of crop residues are returned to the field [183].

Continuous rice double- or triple-cropping results in significant $\mathrm{C}$ and $\mathrm{N}$ accumulation over time until a new equilibrium SOC level is reached, even in systems with all aboveground biomass removed from the field and no farmyard manure applied (Figure 1) [184]. In contrast, SOC content appears to decline in most rice-upland crop systems such as rice-wheat [185]. Nitrogen supply to crops depends on the release of $\mathrm{N}$ from the $\mathrm{SOM}$ via mineralization and supplementation from fertilizer. Nitrogen mineralization rate depends on the substrate concentration (OC and $\mathrm{N}$ ) and environmental factors (soil moisture, aeration, temperature, $\mathrm{pH}$ and availability of other nutrients) which, in turn, are influenced by crop establishment techniques and residue retention practices. The $\mathrm{C}$ and $\mathrm{N}$ cycles in the soil-water-plant agro-ecosystem and the rate of $\mathrm{C}$ and $\mathrm{N}$ release are also continuously being changed by land use and farming/agricultural practices. Ladha and Kessel [186] proposed that the means to sustain soil $\mathrm{C}$ and $\mathrm{N}$ include: (a) Minimizing soil disturbance, (b) avoiding cycles of soil flooding/drying, (c) avoiding dry fallow, (d) using quality residue, (e) replenishing soil nutrients, (f) applying plant need-based N and (g) subsurface application of fertilizer N. Silgram and Shepherd [187], Malhi et al. [188] and Alvarez and Steinbach [189] found SOM mineralization and nitrate $\left(\mathrm{NO}_{3}\right)$ release are stimulated by conventional tillage, whereas Meena et al. [190], Kushwaha et al. [154] found stimulated $\mathrm{SOM}$ mineralization and $\mathrm{NO}_{3}$ release by residue retention practices.

A schematic of the $\mathrm{C}$ cycle in two triple-cropped rotations in northwest Bangladesh is shown in Figure 2. The LCA for greenhouse gas emissions by monsoon rice [191], irrigated rice [192] and for the mustard-irrigated rice-monsoon rice rotation [27] have been reported. Soil respiration (emission of $\mathrm{CO}_{2}$ ) can strongly influence net carbon uptake from the atmosphere, or net ecosystem production [193] 
The $\mathrm{CH}_{4}$ emission by rice soils which results from $\mathrm{CH}_{4}$ production in anoxic zones was the major component of the $\mathrm{C}$ footprint for each of the rice crops and for the annual rotation. $\mathrm{N}_{2} \mathrm{O}$ is emitted to the atmosphere through nitrification [194] and denitrification processes after inorganic or organic fertilization [195], but was a minor contributor to GHG emissions from rice crops and indeed from the annual rotation. Crop rotation [7], residue retention and soil disturbance associated with tillage [162] alter the $\mathrm{C}$ dynamics by affecting the in-season turnover of $\mathrm{C}$ and $\mathrm{N}$, as well as the sequestration of $\mathrm{C}$ and $\mathrm{N}$. The residue types of crops in each cropping sequence, episodes of wetting, drying and re-wetting of soils under rice-upland rotations and amount and types of fertilizer use regulates the decay of potentially mineralizable and resistant fractions of $C$ and $N$ in soils $[42,52,196]$ and ultimately determines the rate of accumulation of $\mathrm{C}$ and $\mathrm{N}$ in soils (Figure 1).
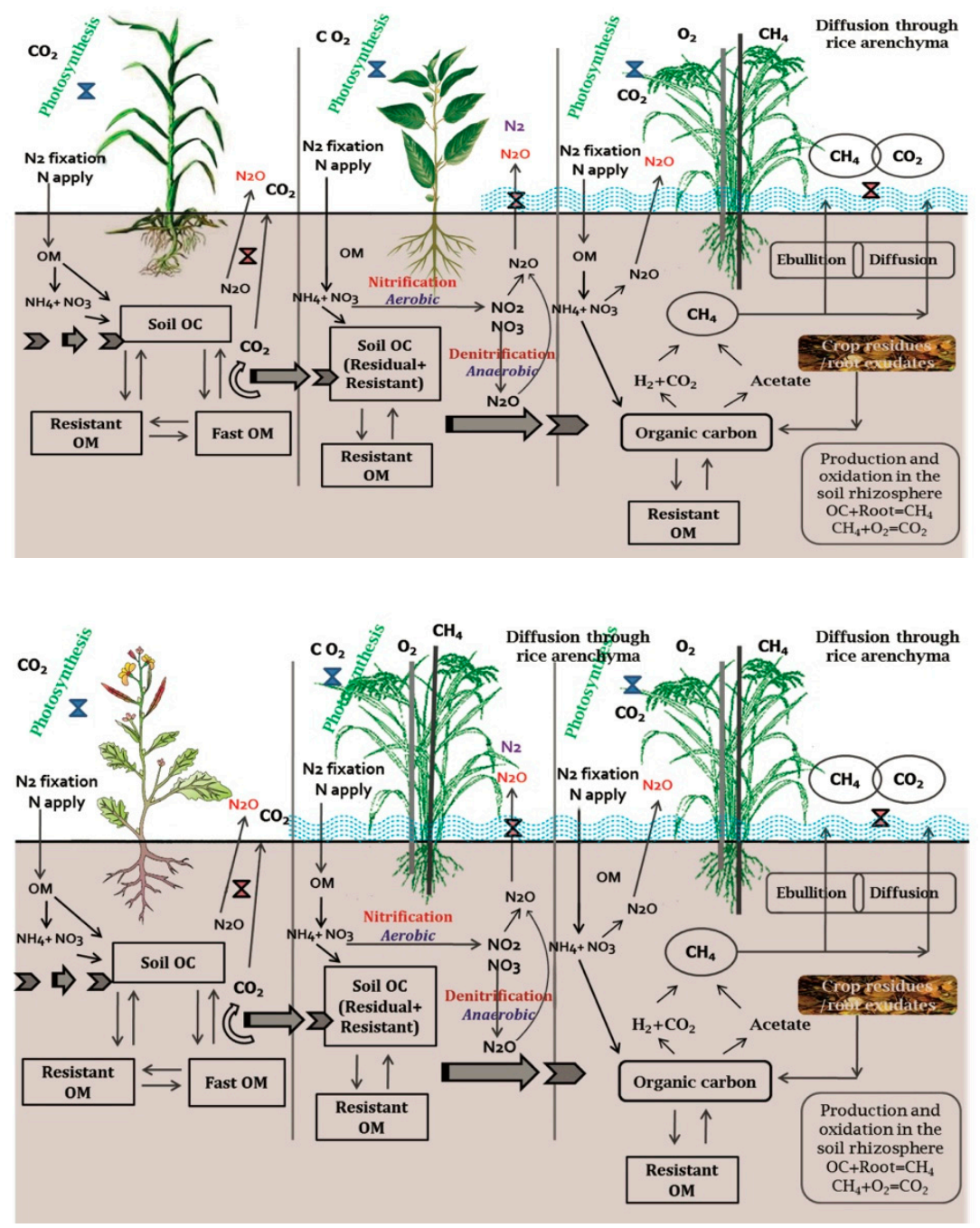

Figure 1. Conceptual diagram of C cycle of rice-based, triple cropping systems Source: Alam [53]. The figure above has crops in rice-anchored rotation of maize-jute-monsoon rice, while the figure below has crops in rice dominant rotation of mustard-irrigated rice-monsoon rice. The figures show how different cropping systems with varied type and amount of residue addition, crop management practices (e.g., irrigation water management) regulate $\mathrm{C}$ and $\mathrm{N}$ dynamics and their biogeochemical cycles.

\section{Tradeoffs of Crop Establishment Practices on Greenhouse Gas Emissions}

The three major GHGs emitted from crop fields are the products of biogeochemical cycles of $\mathrm{C}$ and $\mathrm{N}$ [197]. The change in $\mathrm{C}$ and $\mathrm{N}$ turnover and storage in soils by replacement of conventional practices with modified establishment practices under CA principles may alter the biochemical and 
geochemical processes which may lead to changes in emissions (fluxes) [52]. Emission of GHG from rice fields is very sensitive to crop establishment techniques and management practices [192,198]. It is complicated because the rice crop establishment methods that reduce methane $\left(\mathrm{CH}_{4}\right)$ emission generally increase $\mathrm{N}_{2} \mathrm{O}$ emission. Methods/ and strategies need to be developed which would minimize all the GHGs [198]. The trade-off between $\mathrm{CH}_{4}$ and $\mathrm{N}_{2} \mathrm{O}$ resulting from soil, water or chemical management is a major hurdle in reducing GWP of wetland rice in rice-upland triple cropping systems [198]. Crop establishment strategies that would reduce emissions of both $\mathrm{CH}_{4}$ and $\mathrm{N}_{2} \mathrm{O}$ at the same time would be ideal for fitting in the rice-based systems as alternatives for conventional practices [94]. As the low soil oxygen content and soil redox potential under the saturated soil condition of puddled soil stimulates the activity of methanogens [65], $\mathrm{CH}_{4}$ is the predominant $\mathrm{GHG}$ emission from conventional puddled transplanted rice [199]. No-tillage reduced $\mathrm{CH}_{4}$ emissions with rice straw placed on the soil surface and the soils under those conditions were more oxidised than those of conventional practice [200].

The direct seeding of rice in dry soil (DSR) decreased $\mathrm{CH}_{4}$ emission as DSR fields were not continuously submerged with water [201,202] but the DSR increased $\mathrm{N}_{2} \mathrm{O}$ emission due to the aerobic conditions. The overall net effect of DSR would be to decrease the GWP by a quarter (16-33\%) if the entire area of the IGP under CT could be converted to DSR for the rice-based cropping system [203]. The resource-saving technology, SRI, also had 1.5 times greater $\mathrm{N}_{2} \mathrm{O}$ release due to the increased soil aeration [204]. Conventional tillage followed by dry DSR has the potential to drastically reduce $\mathrm{CH}_{4}$ emissions by up to $60 \%$, though it is known to create conditions for the emission of $\mathrm{N}_{2} \mathrm{O}$ [205]. Overall, the GWP could be decreased as the increase in GWP due to $\mathrm{N}_{2} \mathrm{O}$ emissions could be more than offset by the decrease in $\mathrm{CH}_{4}$ emissions, provided excess fertilizer- $\mathrm{N}$ is not applied [206]. Chakraborty et al. [6] in a global data meta-analysis found that $\mathrm{CH}_{4}$ emissions were also significantly lower in conventional tillage DSR under wet and dry conditions, and ZT DSR under wet condition. The largest $\mathrm{CH}_{4}$ emission reduction $(63 \%)$ was recorded in ZT DSR under dry condition while the reduction in CT DSR under dry condition was $44 \%$. In CT DSR, $\mathrm{CH}_{4}$ emission was $60 \%$ less than in conventional puddled transplanting of rice under wet condition. The $\mathrm{N}_{2} \mathrm{O}$ emissions was increased by $34 \%$ in CT DSR while under non-puddled transplanting under wet condition and ZT DSR under dry condition, $\mathrm{N}_{2} \mathrm{O}$ emissions remained unchanged.

Mechanisms of GHG synthesis and emissions from rice soils have been studied extensively in almost all major rice growing soils and climates [207]. The novel establishment practices that fit CA in rice based intensive cropping systems have different soil conditions in terms of tillage intensity, crop growth duration, water table, nutrient availability, residue retention, episodes of wetting and rewetting. Hence the emission mechanisms and rates under the novel cultivation practices should be studied to identify options for reducing the emissions of the global warming gases from rice soils and from rice-based intensive cropping systems. The emerging NP of rice using bed planting, or SP, as a form of CA for rice establishment, can be an alternative to reduce emissions of $\mathrm{CH}_{4}$ and $\mathrm{N}_{2} \mathrm{O}$ and GWP. For irrigated rice, the NP of rice avoided $29 \%$ and $16 \%$ of life cycle GHG in comparison with conventional puddling with increased and low residue retention, respectively [192]. For all crops in the mustard-irrigated rice-monsoon rice cropping system, Alam et al. [27] reported that NP of rice and strip planting for upland crops with either low or increased residue retention were the best actual life cycle GHG mitigation options. With the accumulation of SOC in CA cropping after 5 years, the life cycle GHG savings with the NP of rice and strip plating for upland crops were $46 \%$ relative to current farmers practice.

The promising crop establishment practices (like NP, DSR, zero-till-seeding or SRI) which can fit CA in rice-based triple cropping systems should be studied through LCA for estimating the potential of GWP mitigation. The crop establishment practices should also be studied for their $C$ footprint under residue retention practices. The crop establishment practices are related to other management practices (fertilizer management, irrigation water management, pesticide application etc.). However, the longer aerobic period during crop establishment under drill-seeding and DSR practices may increase $\mathrm{N}_{2} \mathrm{O}$ emissions [208] and lead to higher GWP values. Drill-seeded rice establishment systems can lead to 
significant $\mathrm{CH}_{4}$ and $\mathrm{N}_{2} \mathrm{O}$ emissions due to fluctuations between anaerobic and aerobic soil conditions, however, the relationship between crop management practices, particularly fertilizer $\mathrm{N}$ management, and total global warming potential (GWP) remains unclear [209]. To date, no comprehensive studies with LCA have been carried out to evaluate the impacts of the DSR and drill-seeded rice system on GHG emission.

\section{Mid-Season Wetting and Drying of Rice Soils and GHG Implications}

Soil moisture influences soil processes (methanogenesis, respiration, nitrification/denitrification) responsible for biogenic emissions of GHGs (Figure 2) [210-212]. In general, increasing soil moisture would increase $\mathrm{CO}_{2}$ and $\mathrm{N}_{2} \mathrm{O}$ evolution up to an optimum level, above which it would reduce $\mathrm{CO}_{2}$ and $\mathrm{N}_{2} \mathrm{O}$ emission but increase $\mathrm{CH}_{4}$ emission due to restricted availability of $\mathrm{O}_{2}$. Periodic drying and wetting of soil has a pronounced influence on $\mathrm{CO}_{2}$ and $\mathrm{N}_{2} \mathrm{O}$ emission. With the rewetting of dried soils the suppressed microbial activity switches up with the release of gases trapped in the soil pores contributing to an increase in $\mathrm{CO}_{2}$ evolution [213]. Investigations confirmed that $\mathrm{N}$ losses are stimulated by cyclic anaerobic and aerobic scenarios [214], especially through the emission of $\mathrm{N}_{2} \mathrm{O}$ [215]. Cai et al. [208] observed a $\mathrm{N}_{2} \mathrm{O}$ flush in irrigated rice fields after floodwater was drained out. Since $\mathrm{N}_{2} \mathrm{O}$ production from both nitrification and denitrification processes is sensitive to $\mathrm{O}_{2}$ concentration, there are reasons to suspect that flooding (anaerobic condition) and draining (aerobic condition) of a soil will influence $\mathrm{N}_{2} \mathrm{O}$ emissions. Though diffusive transport of gases is severely restricted in waterlogged soil, $\mathrm{N}_{2} \mathrm{O}$ can be produced and emitted to the atmosphere in soils when the standing water drains away (Figure 2).

The denitrification process occurs in the upper flooded cultivated layer of soil and in the deeper saturated soil layer as well [216]. It is recognized that after deploying alternate dry-wet periods and after the switch from wetland rice to winter upland crop, $\mathrm{N}_{2} \mathrm{O}$ produced in the subsurface saturated soil layer possibly will move upwards accompanied with water evaporation and be freed as atmospheric $\mathrm{N}_{2} \mathrm{O}$ [217]. Moreover, $\mathrm{N}$ containing gases generated from soil microbial processes, can also be emitted to the atmosphere through rice root-stem tissue, though such gases diffuse slowly and can be confined in the saturated soil layer. Yan et al. [218] found that substantial amount of $\mathrm{N}_{2} \mathrm{O}$ was released through rice plants growing in standing water while release was through the soil surface during the absence of floodwater. According to Qin et al. [219], soluble N from mineral fertilizers results in higher levels of $\mathrm{N}_{2} \mathrm{O}$ than the bound organic $\mathrm{N}$, under moist soil conditions. When a suitable nitrate source is available, soil moisture and available $\mathrm{C}$ enhances the production of $\mathrm{N}_{2} \mathrm{O}$.

The fallow period between crops is often neglected in studies of GHG [27] but substantial amounts of $\mathrm{N}_{2} \mathrm{O}$ could be emitted during these periods, while discharges are generally reduced during flooding periods [220] and during alternate flooding-drying cycle as in porous soils [221]. Aulakh et al. [221] reported $\mathrm{N}_{2} \mathrm{O}$ production during rice growing season is $15-450 \mathrm{~g} \mathrm{~N}_{2} \mathrm{O}-\mathrm{N} \mathrm{ha}^{-1} \mathrm{~d}^{-1}$ and in a well-drained sandy loam soil ranging from $15-60 \mathrm{~g} \mathrm{~N}_{2} \mathrm{O}-\mathrm{N} \mathrm{ha}^{-1} \mathrm{~d}^{-1}$ during pre-rice fallow period. In Northwest India, $\mathrm{N}_{2} \mathrm{O}$ release rates during post-rice fallow and wheat crop were $20-43$ and 5-33 g N $\mathrm{N}_{2} \mathrm{O}-\mathrm{N} \mathrm{ha}^{-1}$ $\mathrm{d}^{-1}$ respectively, resulting in seasonal flux of 2.6-3.4 $\mathrm{kg} \mathrm{N}_{2} \mathrm{O}-\mathrm{N} \mathrm{ha}^{-1}$ [221].

The water regime of rice soil is a major factor controlling $\mathrm{CH}_{4}$ emission [210,222]. Sass et al. [210] reported that repeated drainage and aeration decreased $\mathrm{CH}_{4}$ emission by $12 \%$ compared to continuous flooding. By contrast, one or more drainage events have also been reported to decrease $\mathrm{CH}_{4}$ emission [223,224]. As a reduction in $\mathrm{CH}_{4}$ emission by mid-season drainage (aeration) was observed in the early field measurement in Japan [225]: Mid-season drainage by stopping irrigation supplies oxygen into soil, resulting in a reduction of $\mathrm{CH}_{4}$ emission and a possible enhancement of $\mathrm{CH}_{4}$ oxidation in soil. Sass et al. [210] tested four water management methods and demonstrated that $\mathrm{CH}_{4}$ emission rates varied markedly with water regime, showing the lowest emission with multiple intermittent draining practices. A reduction in $\mathrm{CH}_{4}$ emission by intermittent irrigation or drainage is also reported in Chinese paddy fields [226]. 


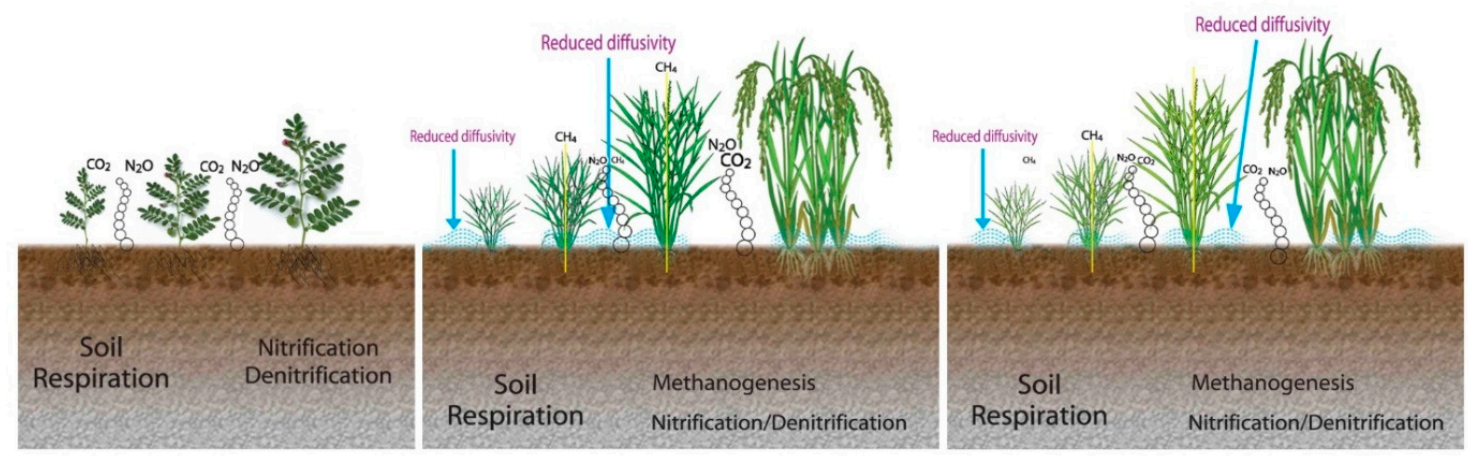

Figure 2. Conceptual diagram of soil processes responsible for greenhouse gas synthesis and emissions under the contrasting wetting and drying conditions in rice-based cropping systems [Adapted from Alam [53]. Soil heterotrophic respiration and nitrification processes mainly take place in aerobic condition to facilitate the emission of $\mathrm{CO}_{2}$ and $\mathrm{N}_{2} \mathrm{O}$, while methanogenesis and denitrification are dominant under anaerobic condition, discharging $\mathrm{CH}_{4}$ mainly and insignificant amount of $\mathrm{N}_{2} \mathrm{O}$ to the atmosphere. In Texas rice fields, average $\mathrm{CH}_{4}$ emission was $106 \mathrm{mg} \mathrm{m}^{-2} \mathrm{~d}^{-1}$ for continuous irrigation, $56 \mathrm{mg} \mathrm{m}^{-2} \mathrm{~d}^{-1}$ when the field was drained in the middle of the cropping cycle, $13 \mathrm{mg} \mathrm{m}^{-2}$ $\mathrm{d}^{-1}$ when the field was drained three times and $151 \mathrm{mg} \mathrm{m}^{-2} \mathrm{~d}^{-1}$ for a late continuous irrigation [210]. Water management between crops is also an important factor. A dry fallow emitted less $\mathrm{CH}_{4}$ during the next crop cycle than a wet fallow [227]. Increasing water percolation in soil might also reduce $\mathrm{CH}_{4}$ emission [228].

During the cultivation of upland wheat crop and the fallow periods, the soil may consume $\mathrm{CH}_{4}$ [229] or be a minor source of $\mathrm{CH}_{4}$. Application of fertilizer generally lessens $\mathrm{CH}_{4}$ uptake rates [229], and because of that replacing fallow by wheat cultivation may considerably reduce the impact against $\mathrm{CH}_{4}$ emissions during the rice crop. However, the composition of organic residues could become a factor for comparing wetland rice-upland wheat system to wetland rice-upland legume rotations. It is evident that a $\sim 50 \% \mathrm{CH}_{4}$ emissions were recorded when wheat was replaced by cowpea and the rice fields were applied with residues from the previous season [220].

Paddy fields in Central China have been identified with a comparatively high level of $\mathrm{CH}_{4}$ emanations varying from around 200 to $900 \mathrm{~kg} \mathrm{CH}_{4} \mathrm{ha}^{-1}$ under inorganic fertilization [230] and up to $1100 \mathrm{~kg} \mathrm{CH}_{4} \mathrm{ha}^{-1}$ in applying organic amendments [231]. In contrast, emission records from Northern India were substantially lower with only $30 \mathrm{~kg} \mathrm{CH}_{4} \mathrm{ha}^{-1}$ from soils under chemical fertilization [232] and $50 \mathrm{~kg} \mathrm{CH}_{4} \mathrm{ha}^{-1}$ in soils under organic treatment [233]. The Indo-Gangetic plains have high porosity soils (porous soils) for the most part. High percolation rates infer high $\left(\mathrm{O}_{2}\right)$ oxygen input into the soil which hampers $\mathrm{CH}_{4}$ emissions even when the soil is amended with high organic inputs [234]. Long-term minimum disturbance of soil increases soil porosity and thus creates pore continuity in soil $[16,52,235]$. The continuous pores in soil may increase water infiltration and percolation into soil while it might reduce $\mathrm{CH}_{4}$ synthesis and emission through $\mathrm{O}_{2}$ diffusion $[208,228]$.

The low $\mathrm{CH}_{4}$ emissions can be elucidated by both the revival of oxidants, e.g., $\mathrm{Fe}^{+3}$ and sulfate concentration [236], and a declining availability of methanogenic archaea in the long-stay aerated soil conditions following upland crop cultivation [201,237]. The increased abundance of oxidants and a lack of methanogens results in a delayed commencement of $\mathrm{CH}_{4}$ production at the beginning of WS paddy cultivation with wheat straw retention.

\section{Tradeoffs of Novel Crop Establishment Practices on Yield Performance of Rice}

There are positive effects worldwide on soil and environment benefits also from establishing rice in rice based cropping system using CA approaches. However, to convince farmers to adopt CA practices for rice establishment needs empirical evidence of yield benefits. A global analysis of rice crop performances by Chakraborty et al. [6] under different crop establishment practices on farmers' field and on research stations ( 323 on-station and 9 on-farm studies) shows that rice yield response to 
tillage/crop establishment practices depended on soil texture and showed a mixed trend. Rice grain yield in clay type soils under ZT versus CT increased by an average of $3.5 \%$. The yield was reduced by $2.9 \%$ and $8.2 \%$ in medium loamy and coarse loamy soil groups, respectively, while the yield remained unchanged in moderately fine loamy soil.

In an experiment on sandy loam soil, Talla and Jena [238] recorded the highest grain yield by following SRI $\left(5.02 \mathrm{t} \mathrm{ha}^{-1}\right)$ followed by transplanting $\left(4.36 \mathrm{t} \mathrm{ha}^{-1}\right)$ and the lowest grain yield was recorded by following dry seeding $\left(2.95 \mathrm{t} \mathrm{ha}^{-1}\right)$. At Banglore on red clay loam soils, Hugar et al. [239] reported that SRI method resulted in significantly higher grain yield $\left(6.1 \mathrm{tha}^{-1}\right)$ compared to aerobic and conventional method. The results are conformed to the outcomes of Jayadeva and Shetty [240] (red clay loam soil) experiments. Hugar et al. [239] and Chandrapala et al. [241] observed higher biological yield with SRI establishment method when compared with direct sowing and transplanting method during wet season on red clay loam soils. However, SRI methods produced similar grain yields to the CT [242]. With irrigated applied, the yield with SRI was increased by $78 \%$ in Indonesia [243] to $244 \%$ in The Gambia [244], while with rain-fed SRI methods, the benefits were from $32 \%$ in India [245] to $100 \%$ or more in Myanmar [246]. On the other hand, Kumar [247] found the lowest grain yield in case of direct seeding under wet condition, while, in sandy clay loam soil, Kumar $[139,247]$ recorded an increase in grain yield ha ${ }^{-1}$ by $9.3 \%$ under machine planting in SRI over normal (conventional) planting method. Regardless of soil types and experimental locations, Kumar [248] obtained 7-20\% higher grain yield in SRI over conventional method. Increased grain yield under SRI can be attributed to the positive effects of adjustment in the establishment practices. The modification includes transplanting 8-10 days old seedlings, controlled irrigation and repeated topsoil disturbance so that aerobic soil conditions could be provided. The younger seedlings which have increased tillering and rooting might be the reason for higher yielding with SRI method [81]. Jayadeva and Shetty [240] and Satyanarayana and Babu [249] attributed the increased yield to greater root density (mass and length), large and fertile tillers, long panicles with increased filled-spikelets and higher grain weight. On the other hand, Bhowmick et al. [250] reported that continuous submergence lowers yields under normal transplanting because rice roots may degenerate with age of the crop. By contrast with the above, some field trials and farmer fields have recorded $1 \%$ to $55 \%$ decrease in yield from the SRI compared to conventional puddled practice [31]. Other researchers have contested the reported yield gains of SRI over conventional practices. The extremely high yield benefits reported in some SRI studies might be errors in measuring yield [220]. Sheehy et al. [242] also found using crop simulation models and by conducting experiments in the climate of Madagascar and in three places of China that some of the reported high yields are not realistic.

All the tillage followed by crop establishment options had yield responses from $-14.7 \%$ to $+14.2 \%$ depending on soil textural classes [6]. The ZT DSR under dry condition showed a reduction of yield from $8.5 \%$ to $13.2 \%$ in textural groups of finer to coarser loam, respectively. Likewise, light textural soils (sandy soils) and loamy moderate-texture soil had a $14.7 \%$ and $10.2 \%$ lower yield under the practice, respectively. On the other hand, a significantly positive yield response to the same establishment practice ( $14.2 \%$ increase) was observed in clayey groups, while the ZT DSR had yield unchanged in all other soils.

Chakraborty et al. [6] reported that reduced tillage non-puddled transplanting of rice under wet condition gave rise to reduced yield ( $7.3 \%$ to $15.3 \%$ lower) in all the soil texture-groups. Constraints relating to manual transplanting could be overcome through mechanized transplanting [6]. By contrast, in an extensive series of on-farm experiments in northwest Bangladesh, Haque et al. [251] found insignificant differences in yield of paddy rice between NP and puddled transplanting methods during both monsoon and irrigated rice seasons. Indeed in some locations and years, they recorded better yields of rice grain in case of NP following strip planting than after puddled transplanting. Strip planting followed by NP rice transplanting outperformed conventional puddling for irrigated rice in 29 on-farm demonstration sites of northwest Bangladesh. 
In three long-term experiments with up to 15 consecutive crops since commencing strip tillage, Haque et al. [19], found an increase in yield of rice grain by 0.7 to $1.7 \mathrm{t} \mathrm{ha}^{-1}$ in all crops under NP transplanting following strip tillage. Collectively, the replicated experiments and on-farms assessments of NP establishment demonstrate that it is a reliable method producing equivalent grain yield in the first crop to the conventional puddling of soils. Continuation of strip tillage and NP transplanting over times produced the yield of both monsoon and irrigated rice crops equal to or greater than those of the conventional puddling and transplanting of rice. With mechanized transplanting, the grain yield was similar between NP transplanting and conventional soil puddling for rice establishment [91]. While changing to NP transplanting represents minimal risk of yield loss for rice producers it provides labor, fuel and water savings.

In another study on a loamy soil, strip planting followed by NP transplanting of rice together with increased residue retention yielded the higher grain of both summer rice $\left(5.97 \mathrm{t} \mathrm{ha}^{-1}\right)$ and winter rice (4.81 ha ${ }^{-1}$ ) than conventional puddled transplanting of rice without residue retention [252] which the authors attributed to mineralizing residue and release of nutrients which promote crop growth and facilitates higher yield over no residue.

Bell et al. [20] found significantly higher grain yields and higher net return for all upland crops in SP grown in rice fields compared to BP and CT. In the first two years, there had no significant variation in rain-fed rice yield using NP transplanting between the tillage systems. Thereafter, significantly higher grain yield of rain-fed rice in NP transplanting was recorded in strip planting.

The inconsistencies reported in yield performance of novel rice crop establishment practices can be partly attributed to the lack of compatible rice varieties. Most of the international and national rice breeding programs aim to develop rice varieties for traditional puddled conditions. As a result, crop novel rice establishment research begins with germplasm biased in favor of the current system. Hence the performance of all the novel rice establishment practices may be improved relative to the conventional puddled transplanting by the use of varieties selected for that establishment method.

Yield declines by DSR (wet and dry) and SRI have been reported in many studies around the world $[253,254]$. The most important contributor to the yield gap with those rice establishment practices is weeds [255], fertilizer and water use, incompatible crop management practices [51], and unsuitable soil and water regimes for each production package [13]. To reduce the risks of yield losses under novel crop establishment practices, more research is required on improved plant nutrition, water and weed management, suitable seeding machines (durability, cost, access to maintenance), and characterizing suitable areas for particular establishment practices.

Fertilizer rates and application methods used for the CA based rice crop establishment practices were developed for conventional puddled transplanting of rice and have not been optimized for CA based rice crop establishment practices. Intensive research should therefore be commenced to determine the optimal nutrient management strategies for $\mathrm{CA}$ and other novel rice establishment practices.

There may be changed insect infestation and disease epidemiology (e.g., rice sheath blight) due to differences in crop residue levels retained and the canopy of rice crop grown under different crop establishment methods [256]. Castilla et al. [257] and Pandey and Velasco [258] reported that high plant population in DSR can make rice crops more disease susceptible. More research on the disease epidemiology and insect control is needed for novel rice establishment practices. Such studies need to be based on long term practice of new establishment methods since the new threats from insects and disease take time to become established.

\section{Tradeoffs of Novel Crop Establishment Practices on Economics}

As cost of rice production following traditional practices is increasing over time, alternative methods of growing crops that are more water efficient and less labor intensive is urgently needed to enable farmers to harvest more with minimized cost of production. On the other hand, novel seeding/transplanting of rice ensures timely crop establishment with reduced labor and water requirements and comparably higher yield than conventional system of establishment. 
Crop establishment practices compliant with CA have demonstrated significant production cost savings as they require lower labor inputs, less fuel consumption and reduced irrigation water supply $[6,259]$. Findings from these studies on the economics of novel rice establishment are summarized in Table 2.

Table 2. Economics of rice crop establishment practices.

\begin{tabular}{|c|c|c|c|}
\hline $\begin{array}{l}\text { Name of the } \\
\text { Researchers }\end{array}$ & $\begin{array}{c}\text { Rice Establishment } \\
\text { Practices }\end{array}$ & Economic Profitability & $\begin{array}{l}\text { Benefit Cost Ratio } \\
\text { (BCR) }\end{array}$ \\
\hline Sharma et al. [65] & $\begin{array}{c}\text { Self-propelled } \\
\text { transplanter and manual } \\
\text { transplanting }\end{array}$ & $\begin{array}{l}\$ 689.01 \mathrm{ha}^{-1} \text { (Self-propelled } \\
\text { transplanter) and } \$ 686.55 \mathrm{ha}^{-1} \\
\text { (manual transplanting) }\end{array}$ & $\begin{array}{c}1.47 \text { (self-propelled } \\
\text { transplanter) and } 1.46 \\
\text { (manual transplanting) }\end{array}$ \\
\hline Singh and Singh [260] & $\begin{array}{l}\text { Drum seeding under } \\
\text { puddled soil condition, } \\
\text { broadcasting of sprouted } \\
\text { seeds under puddled } \\
\text { condition, dry seeding }\end{array}$ & $\begin{array}{l}\$ 379.15 \mathrm{ha}^{-1} \text { (drum seeding } \\
\text { under puddled condition), } \\
\$ 346.37 \mathrm{ha}^{-1} \text { (broadcasting of } \\
\text { sprouted seeds under puddled } \\
\text { condition) and } \$ 292.4 \mathrm{ha}^{-1} \\
\text { (dry seeding) }\end{array}$ & $\begin{array}{c}1.76 \text { (drum seeding } \\
\text { under puddle condition), } \\
\text { wet seeding (1.63) and } \\
1.32 \text { (dry seeding) }\end{array}$ \\
\hline Jha et al. [261] & $\begin{array}{l}\text { Drum seeding of } \\
\text { sprouted seed in } \\
\text { puddled condition, } \\
\text { mechanical transplanting } \\
\text { by self-propelled } \\
\text { transplanter and } \\
\text { manually transplanting }\end{array}$ & $\begin{array}{l}\$ 732.52 \mathrm{ha}^{-1} \text { (drum seeding of } \\
\text { sprouted seed in puddled } \\
\text { condition), } \$ 685.39 \mathrm{ha}^{-1} \\
\text { (mechanical transplanting by } \\
\text { self-propelled transplanter) } \\
\text { and } 639.60 \mathrm{ha}^{-1} \text { (manually } \\
\text { transplanting) }\end{array}$ & $\begin{array}{l}3.2 \text { (drum seeding of } \\
\text { sprouted seed in } \\
\text { puddled condition), } 3.1 \\
\text { (mechanical } \\
\text { transplanting by } \\
\text { self-propelled } \\
\text { transplanter), } 2.1 \\
\text { (manually transplanting) }\end{array}$ \\
\hline Jha et al. [262] & $\begin{array}{c}\text { Mechanical } \\
\text { transplanting, drum } \\
\text { seeding of sprouted seed } \\
\text { in puddled condition } \\
\text { and manually } \\
\text { transplanting }\end{array}$ & $\begin{array}{l}\$ 1063.41 \mathrm{ha}^{-1} \text { (mechanical } \\
\text { transplanting), } \$ 1062.34 \mathrm{ha}^{-1} \\
\text { (drum seeding of sprouted } \\
\text { seed in puddled condition) } \\
\text { and } \$ 998.33 \mathrm{ha}^{-1} \text { (manually } \\
\text { transplanting) }\end{array}$ & $\begin{array}{l}2.38 \text { (mechanical } \\
\text { transplanting), } 2.35 \\
\text { (drum seeding of } \\
\text { sprouted seed in } \\
\text { puddled condition) and } \\
\text { 1.77 (manually } \\
\text { transplanting ) }\end{array}$ \\
\hline Durga and Kumar [263] & $\begin{array}{c}\text { System of rice } \\
\text { intensification and } \\
\text { traditional puddling }\end{array}$ & $\begin{array}{l}\text { (Gross return) } \$ 1016.02 \text { and } \\
\$ 840.72 \mathrm{ha}^{-1}, \text { respectively for } \\
\text { SRI and non-SRI farmers. }\end{array}$ & $\begin{array}{l}1.7 \text { (system of rice } \\
\text { intensification) and } 1.1 \\
\text { (non-SRI farmers). }\end{array}$ \\
\hline Rana et al. [264] & $\begin{array}{l}\text { Direct seeding of } \\
\text { sprouted seeds, manual } \\
\text { transplanting and direct } \\
\text { seeding of dry seeds }\end{array}$ & $\begin{array}{c}\$ 283.35 \text { (direct seeding of } \\
\text { sprouted seeds, } \$ 98.71 \\
\text { (manual transplanting and } \\
\$ 167.54 \text { (direct seeding of dry } \\
\text { seeds) }\end{array}$ & $\begin{array}{c}1.49 \text { (direct seeding of } \\
\text { sprouted seeds), } 1.14 \\
\text { (manual transplanting) } \\
\text { and } 1.30 \text { (direct seeding } \\
\text { of dry seeds) }\end{array}$ \\
\hline Islam et al. [70] & $\begin{array}{l}\text { Puddled transplanting, } \\
\text { single pass wet tillage, } \\
\text { Non-puddling following } \\
\text { strip tillage and bed } \\
\text { planting }\end{array}$ & $\begin{array}{c}\text { (Gross return) } \$ 883.63 \\
\text { (Puddled transplanting), } \\
\$ 856.80 \text { (single pass wet } \\
\text { tillage), } \$ 913.20 \text { (non-puddled } \\
\text { transplanting following strip } \\
\text { tillage) and } \$ 946.44 \text { (following } \\
\text { bed planting) }\end{array}$ & $\begin{array}{c}1.46 \text { (Puddled } \\
\text { transplanting and single } \\
\text { pass wet tillage), } 1.56 \\
\text { (non-puddled } \\
\text { transplanting following } \\
\text { strip tillage) and } 1.61 \\
\text { (following bed planting) }\end{array}$ \\
\hline Salahin [90] & $\begin{array}{l}\text { Zero tillage under } \\
\text { non-puddled condition, } \\
\text { strip tillage under } \\
\text { non-puddled condition, } \\
\text { bed tillage and } \\
\text { conventional tillage }\end{array}$ & $\begin{array}{l}\text { \$267.4 (zero tillage under } \\
\text { non-puddled condition), } \\
\text { \$456.86 (strip tillage under } \\
\text { non-puddled condition), } \\
\text { \$389.91 (bed planting) and } \\
\text { \$271.6 (conventional } \\
\text { puddling) }\end{array}$ & $\begin{array}{c}1.29 \text { (zero tillage under } \\
\text { non-puddled condition), } \\
1.51 \text { (strip tillage under } \\
\text { non-puddled condition), } \\
1.44 \text { (bed planting) and } \\
1.31 \text { (conventional } \\
\text { puddling) }\end{array}$ \\
\hline
\end{tabular}

N.B.: The conversion from Bangladeshi Taka and Indian Rupees were done on 15 October 2017.

Minimum tillage decreases the input costs for labor, fuel, machinery, and other equipment [90]. Chakraborty et al. [6] showed that dry direct seeding of rice under minimum tillage and dry direct seeding under ZT accounted for the greatest reductions in cultivation cost (20\% and $17 \%)$, in comparison with conventional puddled transplanting under wet soil condition. The costs of conventional puddled transplanting under wet condition, sprout seeding under dry condition and NP transplanting under 
minimum tillage soil in wet condition were the same (statistically similar) and ranged from $9 \%$ to $12 \%$ lower than in conventional puddled transplanting. In case of economic returns, direct seeding under puddled condition, dry direct seeding under CT condition and dry direct seeding under ZT had higher economic returns $(13.0 \%, 12.1 \%$ and $25.9 \%$, respectively) over NP transplanting under minimum tillage and dry direct seeding under minimum tillage conditions which had had lower economic returns $(-13.7 \%$ and $-3.0 \%$, respectively). In contrast, Haque et al. [19] found insignificant differences among the NP transplanting following strip planting and bed planting and conventional puddled transplanting for gross return. Haque et al. [19] also reported significantly higher gross margin was accrued for single pass shallow tillage (SPST), bed planting (BP), and strip planting (ST) followed by NP transplanting of rice by about US $\$ 87$, US $\$ 118$ and US $\$ 79 \mathrm{ha}^{-1}$, respectively.

Haque and Bell [265] showed greater profit from NP transplanted rice on farmers' fields. The net profit was up to $59 \%$ greater in NP of rice. From 50\% to $94 \%$ farmers adopting NP of rice in both the irrigated and monsoon seasons reported greater net returns even if there were economic losses due to low rice grain prices.

\section{Problems Reported for Rice Crop Establishment Practices}

Numerous novel establishment methods have been developed for rice to replace the manual transplanting of rice in puddled soils. These have been developed to save labor, water and production costs. They have achieved varied levels of adoption on farms. However, challenges and problems still remain with these practices as summarized below (Table 3 ).

Table 3. Problems Reported for Rice Crop Establishment Practices.

\begin{tabular}{|c|c|c|}
\hline Methods/Techniques & \multicolumn{2}{|c|}{ Problems } \\
\hline \multirow{14}{*}{$\begin{array}{l}\text { Direct seeded rice (DSR) under ZT } \\
\text { (dry/wet)/puddled/non-puddled } \\
\text { (dry/wet) }\end{array}$} & O & Higher emissions of nitrous oxide [266] \\
\hline & 0 & Increase in soil-borne pathogens such as nematodes [266] \\
\hline & 0 & $\begin{array}{l}\text { Severe weed infestation (direct seeded rice under dry } \\
\text { condition in particular) [267] }\end{array}$ \\
\hline & $\bigcirc$ & $\begin{array}{l}\text { Drastic change of weed flora after transition from conventional } \\
\text { puddling to dry soil (DSR) [268] }\end{array}$ \\
\hline & 0 & $\begin{array}{l}\text { Increased use of herbicide and development of herbicides } \\
\text { resistant weeds such as weedy rice or red rice (O. sativa, F. } \\
\text { spontanea) }\end{array}$ \\
\hline & 0 & Severe yield loss from weed infestation [269] \\
\hline & 0 & Development of micronutrient deficiencies such as $\mathrm{Zn} \mathrm{[270]}$ \\
\hline & 0 & Stagnation or decline of yield [271] \\
\hline & 0 & $\begin{array}{l}\text { Lodging in DSR compared to puddled transplanting which } \\
\text { damages the quality of rice grain [272] }\end{array}$ \\
\hline & 0 & $\begin{array}{l}\text { Disease susceptibility such as rice blast [273] under low water } \\
\text { availability [274] }\end{array}$ \\
\hline & & $\begin{array}{l}\text { Heavy early rain may not allow conservation agriculture (CA) } \\
\text { machinery (zero till drills etc.) to operate on fields. }\end{array}$ \\
\hline & 0 & Direct seeding exposes seeds to birds, rats etc. \\
\hline & & $\begin{array}{l}\text { Sudden rain immediately after seeding can adversely affect } \\
\text { crop establishment. }\end{array}$ \\
\hline & & $\begin{array}{l}\text { Uneven crop stand also results in failure to achieve potential } \\
\text { yield of DSR. }\end{array}$ \\
\hline
\end{tabular}


Table 3. Cont

\begin{tabular}{|c|c|c|}
\hline Methods/Techniques & \multicolumn{2}{|c|}{ Problems } \\
\hline \multirow{12}{*}{ System of rice intensification (SRI) } & ○ & $\begin{array}{l}\text { Highly technical beyond farmers' comprehension (knowledge } \\
\text { intensive-suitable varieties, preparation of seedlings, } \\
\text { irrigation and nutrient management) [83]. }\end{array}$ \\
\hline & $\bigcirc$ & $\begin{array}{l}\text { A fixed technological package that farmers are not well aware } \\
\text { of [81]. }\end{array}$ \\
\hline & $\bigcirc$ & $\begin{array}{l}\text { Difficult to harmonize suggested water scheduling with } \\
\text { available irrigation [83] }\end{array}$ \\
\hline & ○ & $\begin{array}{l}\text { Controlled irrigation and provision of adequate drainage } \\
\text { facilities [83] }\end{array}$ \\
\hline & $\bigcirc$ & $\begin{array}{l}\text { Transplanting single } 8-14 \text { days old seedlings require } \\
\text { labor-intensive mechanical weeding practices [81]. }\end{array}$ \\
\hline & $\bigcirc$ & $\begin{array}{l}\text { Organic manure at farm level may not be available and even if } \\
\text { available may cause drawbacks in timely establishment and } \\
\text { eventually sacrifice crop yields [56]. }\end{array}$ \\
\hline & ○ & $\begin{array}{l}\text { Irregular climatic variation may hamper on-farm water } \\
\text { availability (flooding during initial stages, heavy downpour in } \\
\text { season etc.) [275] }\end{array}$ \\
\hline & O & $\begin{array}{l}\text { Articulated rice growing environments may not prevail } \\
{[83,275]}\end{array}$ \\
\hline & $\bigcirc$ & $\begin{array}{l}\text { Articulated soil types may not be found (clay soils can } \\
\text { maintain saturated conditions while loamy soils may need } \\
\text { frequent irrigation) }[83,275] \text {. }\end{array}$ \\
\hline & $\bigcirc$ & May sacrifice yields [83] \\
\hline & $\bigcirc$ & Frequent wetting and drying may cause $\mathrm{C}$ and $\mathrm{N}$ losses \\
\hline & $\bigcirc$ & Higher cost involvement [83] \\
\hline \multirow{12}{*}{$\begin{array}{l}\text { Non-puddled transplanting of rice } \\
\text { following strip tillage or bed } \\
\text { planting }\end{array}$} & $\bigcirc$ & $\begin{array}{l}\text { Lack of drainage in lowland rice may cause delay in } \\
\text { transplanting, prolonged inundation and seedling mortality. }\end{array}$ \\
\hline & $\bigcirc$ & $\begin{array}{l}\text { Mechanization unavailability may hamper timely transplanting } \\
\text { [28] }\end{array}$ \\
\hline & ○ & $\begin{array}{l}\text { Drudgery during rice seedling transplanting if the soils are } \\
\text { hard to penetrate. }\end{array}$ \\
\hline & $\bigcirc$ & $\begin{array}{l}\text { Early monsoon rain may not allow CA equipment (e.g., ZT } \\
\text { drill) to enter the field }\end{array}$ \\
\hline & 0 & Varied efficacy of chemical control of weeds \\
\hline & $\bigcirc$ & Development of herbicide resistant weeds \\
\hline & $\bigcirc$ & $\begin{array}{l}\text { Increased infiltration in light textured, upland soils may lead to } \\
\text { requirement of additional irrigation for rapidly-draining soils } \\
\text { and/or yield reduction. }\end{array}$ \\
\hline & $\bigcirc$ & $\begin{array}{l}\text { Plants/seedlings suffer stresses for establishment if the soils are } \\
\text { hard to root proliferation }\end{array}$ \\
\hline & ○ & $\begin{array}{l}\text { Drying and rewetting of bed tops may increase } C \text { and } N \text { loss } \\
\text { [276] }\end{array}$ \\
\hline & $\bigcirc$ & Farmers' knowledge gap \\
\hline & $\bigcirc$ & Yield reduction reported [6] \\
\hline & $\bigcirc$ & Need further study to validate \\
\hline
\end{tabular}

To minimize or overcome the above challenges and limitations we recommend:

- $\quad$ For every novel rice establishment practice, well tested methods need to be documented in a suitable form for farmers and service providers.

- Machinery to improve the efficiency and reduce the labor requirements of the establishment practice should be developed in partnerships involving farmers and manufacturers.

- Machines or attachments to machines must be able to handle the residue retained while maintaining effective machine operation. 
- As residues are used for household and construction materials, optimum amounts of residue retention should be defined for different soils and cropping systems.

- Mechanization should be provided on accessible terms and conditions, with loans, incentives and subsidies provided if required.

- Mechanical service providers should be fostered and supported to provide hire services for rice establishment.

- Cost-effective and safe weed management strategies should be developed for each of the practices [255].

- Effective nutrient management techniques should also be included with the practice recommended.

- Further study is necessary to determine the domain of soil type and climates (locations) and cropping systems where each establishment practice is reliable.

- Farmers' involvement in experimentation and validation is critical for overturning traditional rice establishment practices.

\section{Conclusions}

The crop establishment practices which outperform or match the existing rice establishment practices in terms of yield, economic benefits and labor requirements and do not require much technical adjustment are most readily adopted by farmers. Researchers or policy makers on the other hand tend to prioritize establishment techniques which conserve soil, water and environmental resources along with the above benefits. Research has been trying to develop and deploy rice establishing practices for the last several decades which satisfy the above criteria for rice based cropping systems, including those that apply CA principles in rice as well as other crops in the rotations. However, all the crop establishment practices have their own limitations when adopted by the end-users. Hence particular methods of rice crop establishment may be more suited than others to specific rice based cropping systems. Further improvements with the practices will be based on farmers' problem-solving and innovation provided the benefits outweigh the costs.

Author Contributions: M.K.A. has outlined and collected most of the papers pertinent to implications of rice crop establishment following CA practices, R.W.B., S.A., M.H.R., and M.H. reviewed the manuscript and suggested for required improvements; M.F.K., H.B.S., M.J.A., N.S., M.S.I. and S.I. wrote some paragraphs related to their research areas (soil properties and yield); M.F.K., H.B.S., M.M.R.B.A., M.F.A.A. and S.N. wrote biological properties portion of the manuscript; S.I., N.A., M.S.I. and S.I. wrote economics of rice crop establishment and finally reviewed before submission. All authors have read and agreed to the published version of the manuscript.

Funding: This review was partly completed while the senior author held a John Allwright Fellowship provided by the Australian Centre for International Agricultural Research.

Acknowledgments: The authors would like to thank libraries and librarians of BARI, Murdoch University and University of Newcastle for access to their facilities. Thanks are also due to many researchers who have sent published papers personally for writing this manuscript.

Conflicts of Interest: The authors hereby declare that there will remain no conflict of interest to publish the manuscript.

\section{References}

1. FAOSTAT. Statistics Division Food and Agriculture Organization of the United Nations; Viale delle Terme di Caracalla: Rome, Italy, 2019.

2. Bell, R.W.; Haque, M.E.; Jahiruddin, M.; Rahman, M.M.; Begum, M.; Miah, M.A.M.; Islam, M.A.; Hossen, M.A.; Salahin, N.; Zahan, T.; et al. Conservation agriculture for rice-based intensive cropping by smallholders in the eastern Gangetic plain. Agriculture 2019, 9, 5. [CrossRef]

3. Papademetriou, M.K. Rice Production in the Asia-Pacific Region: Issues and Perspectives. In Bridging the Rice Yield Gap in the Asia and Pacific Region; The FAO Regional Office for Asia and the Pacific: Bangkok, Thailand, 1999.

4. Van Nguyen, N.; Ferrero, A. Meeting the challenges of global rice production. Paddy Water Environ. 2006, 4, 1-9. [CrossRef] 
5. Gupta, R.; Seth, A. A review of resource conserving technologies for sustainable management of the rice-wheat cropping systems of Indo-Gangetic plains (IGP). Crop Prot. 2007, 26, 436-447. [CrossRef]

6. Chakraborty, D.; Ladha, J.K.; Rana, D.S.; Jat, M.L.; Gathala, M.K.; Yadav, S.; Rao, A.N.; Ramesha, M.S.; Raman, A. A global analysis of alternative tillage and crop establishment practices for economically and environmentally efficient rice production. Sci. Rep. 2017, 7, 9342. [CrossRef]

7. Alam, M.K.; Salahin, N.; Islam, S.; Begum, R.A.; Hasanuzzaman, M.; Islam, M.S.; Rahman, M.M. Patterns of change in soil organic matter, physical properties and crop productivity under tillage practices and cropping systems in Bangladesh. J. Agric. Sci. 2016, 155, 216-238. [CrossRef]

8. Barker, R.; Dawe, D.; Tuong, T.P.; Bhuiyan, S.I.; Guerra, L.C. The outlook for water resources in the year 2020: Challenges for research on water management in rice production in Assessment and Orientation Towards the 21st Century. Southeast Asia 1999, 1, 1-5.

9. Bouman, B.A.M.; Lampayan, R.M.; Tuong, T.P. Water Management in Irrigated Rice: Coping with Water Scarcity; International Rice Research Institute: Los Baños, Philippines, 2007; pp. 1-54.

10. Chauhan, B.S.; Opeña, J. Effect of tillage systems and herbicides on weed emergence, weed growth, and grain yield in dry-seeded rice systems. Field Crops Res. 2012, 137, 56-69. [CrossRef]

11. Tuong, T.P.; Bouman, B.A.M. Rice Production in Water Scarce Environments in Water Productivity in Agriculture: Limits and Opportunities for Improvement; Kijne, J.W., Barker, R., Molden, D., Eds.; CABI Publishing: Wallingford, UK, 2002; pp. 13-42.

12. Singh, S.; Sharma, A.K. Gender issues for drudgery reduction and sustainable small holder farming in rice production system. J. Hill Agric. 2012, 3, 99-102.

13. FICCI (Federation of Indian Chambers of Commerce \& Industry). Labour in Indian Agriculture: A Growing Challenge. 2015. Available online: http://ficci.in/spdocument/20550/FICCI-agri-Report\%2009-03-2015.pdf (accessed on 18 May 2016).

14. Zhang, W.; Yu, Y.; Huang, Y.; Li, T.; Wang, P. Modelling methane emissions from irrigated rice cultivation in China from 1960 to 2050. Glob. Chang. Biol. 2011, 17, 3511-3523. [CrossRef]

15. IPCC. Climate Change 2013: The Physical Science Basis, Contribution of Working Group I to the Fifth Assessment Report of the Intergovernmental Panel on Climate Change; Stocker, T.F., Qin, D., Plattner, G.K., Tignor, M., Allen, S.K., Boschung, J., Nauels, A., Xia, Y., Bex, V., Midgley, P.M., Eds.; Cambridge University Press: Cambridge, UK; New York, NY, USA, 2013; p. 1535.

16. Alam, M.K.; Islam, M.M.; Salahin, N.; Hasanuzzaman, M. Effect of tillage practices on soil properties and crop productivity in wheat-mungbean-rice cropping system under subtropical climatic conditions. Sci. World J. 2014, 10, 40-55. [CrossRef]

17. Gupta, R.; Sayre, K. Conservation agriculture in South Asia. J. Agric. Sci. 2007, 145, 207-214. [CrossRef]

18. Khurshid, K.; Iqbal, M.; Arif, M.S.; Nawaz, A. Effect of tillage and mulch on soil physical properties and growth of maize. Int. J. Agric. Biol. 2006, 8, 593-596.

19. Haque, M.E.; Bell, R.W.; Islam, M.A.; Rahman, M.A. Minimum tillage unpuddled transplanting: An alternative crop establishment strategy for rice in conservation agriculture cropping systems. Field Crops Res. 2016, 185, 31-39. [CrossRef]

20. Bell, R.W.; Haque, M.E.; Islam, M.A.; Alam, M.K.; Jahiruddin, M. Long-Term Impact of Conservation Agriculture in Rice-Based Cropping Systems; World Congress on Conservation Agriculture: Rosario, Agrentina, 2017.

21. Ladha, J.K.; Pathak, H.; Tirol-Padre, A.; Dawe, D.; Gupta, R.K. Productivity trends in intensive rice-wheat cropping systems in Asia. In Improving the Productivity and Sustainability of Rice-Wheat Systems: Issues and Impacts; Ladha, J.K., Pathak, H., Tirol-Padre, A., Dawe, D., Gupta, R.K., Eds.; ASA, CSSA, and SSSA: Madison, WI, USA, 2003; pp. 45-76.

22. Zhou, W.; Lv, T.F.; Chen, Y.; Westby, A.P.; Ren, W.J. Soil physicochemical and biological properties of paddy-upland rotation: A review. Sci. World J. 2014, 2014, 856352. [CrossRef]

23. Islam, M.A. Conservation Agriculture: Its Effects on Crop and Soil in Rice-Based Cropping Systems in Bangladesh. Ph.D. Thesis, School of Veterinary and Life Sciences, Murdoch University, Murdoch, Australia, 2017.

24. Lal, R. Carbon emissions from farm operations. Environ. Int. 2004, 30, 981-990. [CrossRef]

25. Salahin, N.; Islam, M.S.; Begum, R.A.; Alam, M.K.; Hossain, K.M.F. Effect of tillage and integrated nutrient management on soil physical properties and yield under tomato-mungbean-t.aman cropping pattern. Int. J. Sustain. Crop Prod. 2011, 6, 58-62.

26. Sanchez, P.A. Puddling tropical soils. 2. Effects on water losses. Soil Sci. 1973, 115, 303-308. [CrossRef] 
27. Alam, M.K.; Biswas, W.K.; Bell, R.W. Decreasing the carbon footprint of an intensive rice-based cropping system using conservation agriculture on the Eastern Gangetic Plains. J. Clean. Prod. 2019, 218, $259-272$. [CrossRef]

28. Johansen, C.; Haque, M.E.; Bell, R.W.; Thierfelder, C.; Esdaile, R.J. Conservation agriculture for small holder rainfed farming: Opportunities and constraints of new mechanized seeding systems. Field Crop. Res. 2012, 132, 18-32. [CrossRef]

29. Scheltema, W. Puddling Against Dry Plowing for Lowland Rice Culture in Surinam; Centre for Agricultural Publishing and Documentation: Wageningen, The Netherlands, 1974; p. 241.

30. Ringrose-Voase, A.J.; Kirby, J.M.; Djoyowasito, G.; Sanidad, W.B.; Serrano, C.; Lando, T.M. Changes to the physical properties of soils puddled for rice during drying. Soil Tillage Res. 2000, 56, 83-104. [CrossRef]

31. McDonald, A.J.; Hobbs, P.R.; Riha, S.J. Does the System of Rice Intensification outperform conventional best management? A synopsis of the empirical record. Field Crops Res. 2006, 96, 31-36. [CrossRef]

32. Kirchhof, G.; Priyono, S.; Utomo, W.H.; Adisarwanto, T.; Dacanay, E.V.; So, H.B. The effect of soil puddling on the soil physical properties and the growth of rice and post-rice crops. Soil Tillage Res. 2000, 56, 37-50. [CrossRef]

33. Salahin, N. Influence of Minimum Tillage and Crop Residue Retention on Soil Organic Matter, Nutrient Content and Crop Productivity in the Rice- Jute System. Ph.D. Thesis, Department of Soil Science, Bangladesh Agricultural University, Mymensingh, Bangladesh, 2017.

34. Hobbs, P.; Morris, M. Meeting South Asia's Future Food Requirements From Rice-Wheat Cropping Systems; Priority Issues Facing Researchers in the Post-Green Revolution Era; Natural Resource Group Paper 96-01; CIMMYT: Mexico, 1996.

35. Sharma, P.; Tripathi, R.P.; Singh, S. Tillage effects on soil physical properties and performance of rice-wheat-cropping system under shallow water table conditions of Tarai, Northern India. Eur. J. Agron. 2005, 23, 327-335. [CrossRef]

36. Aggarwal, G.C.; Sidhu, A.S.; Sekhon, N.K.; Sandhu, K.S.; Sur, H.S. Puddling and N management effects on crop response in a rice-wheat cropping system. Soil Tillage Res. 1995, 36, 129-139. [CrossRef]

37. Jat, M.L.; Gathala, M.K.; Ladha, J.K.; Saharawat, Y.S.; Jat, A.S.; Kumar, V.; Sharma, S.K.; Kumar, V.; Gupta, R. Evaluation of precision land leveling and double zero-till systems in the rice-wheat rotation: Water use, productivity, profitability and soil physical properties. Soil Tillage Res. 2009, 105, 112-121. [CrossRef]

38. Shukla, M.K.; Lal, R.; Unkefer, P. Experimental evaluation of infiltration models for different land use and soil management systems. Soil Sci. 2003, 168, 178-191. [CrossRef]

39. Behera, B.K.; Varshney, B.P.; Goel, A.K. Effect of puddling on puddled soil characteristics and performance of selfpropelled transplanter in rice crop. Agric. Eng. Int. CIGRE J. 2009, 10, 20.

40. Saroch, K.; Thakur, R.C. Effect of Puddling (Wt Tillage) on Rice Yield and Physico-Chemiclal Properties of Soil; Department of Agronomy and Agro meteorology, Krishi Vishvavidya Laya: Palampur, India, 1991; Volume 21, pp. 147-152.

41. Ponnamperuma, F.N. Physico-Chemical Properties of Submerged Soils in Relation to Fertility; IRRI Res. Pap. Ser. No. 5; International Rice Research Institute: Los Banos, Philippines, 1977; p. 32.

42. Alam, M.K.; Bell, R.W.; Haque, M.E.; Islam, M.A.; Kader, M.A. Soil nitrogen storage and availability to crops are increased by conservation agriculture practices in rice-based cropping systems in the Eastern Gangetic Plains. Field Crops Res. 2020, 250, 107764. [CrossRef]

43. Pekrun, C.; Kaul, H.P.; Claupein, W. Soil tillage for sustainable nutrient management. In Soil Tillage in Agroecosystems; El Titi, A., Ed.; CRC Press: Boca Raton, FL, USA, 2003; pp. 83-113.

44. Palma, R.M.; Saubidet, M.I.; Rimolo, M.; Utsumi, J. Nitrogen losses by volatilization in a corn crop with two tillage systems in the Argentine Pampa. Commun. Soil Sci. Plant Anal. 1998, 29, 2865-2879. [CrossRef]

45. McGarry, S.J.; O'Toole, P.; Morgan, M.A. Effects of soil temperature and moisture content on ammonia volatilization from urea-treated pasture and tillage soils. Ir. J. Agric. Food Res. 1987, 26, 173-182.

46. Bibhash, C.V.; Datta, S.P.; Rattan, R.K.; Singh, A.K. Monitoring changes in soil organic carbon pools, nitrogen, phosphorus, and sulfur under different agricultural management practices in the tropics. Environ. Monit. Assess. 2010, 171, 579-593.

47. Singh, G.R.; Pandya, K.S.; Chaure, N.K.; Parihar, S.S.; Choudhary, K. Soil fertility, productivity and profitability of rice under different organic manures. Oryza 2000, 37, 208-212. 
48. Pathak, H.; Saharawat, Y.S.; Gathala, M.; Ladha, J.K. Impact of resource-conserving technologies on productivity and greenhouse gas emissions in the rice-wheat system. Greenh. Gases Sci. Technol. 2011, 1, 1-17. [CrossRef]

49. Six, J.; Elliott, E.T.; Paustian, K. Aggregate and soil organic matter dynamics under conventional and no-tillage systems. Soil Sci. Soc. Am. J. 1999, 63, 1350-1358. [CrossRef]

50. Banerjee, B.; Aggarwal, P.K.; Pathak, H.; Singh, A.K.; Chaudhary, A. Dynamics of organic carbon and microbial biomass in alluvial soil with tillage and amendments in rice-wheat systems. Environ. Monit. Assess. 2006, 119, 173-189. [CrossRef]

51. Sharma, P.K.; De Datta, S.K. Effects of puddling on soil phuysical properties and processes. In Soil Physics and Rice; International Rice Research Institute: Los Banos, Phillippines, 1985; pp. 217-234.

52. Alam, M.K.; Bell, R.W.; Haque, M.E.; Kader, M.A. Minimal soil disturbance and increased residue retention increase soil carbon in rice-based cropping systems on the Eastern Gangetic Plain. Soil Tillage Res. 2018, 183, 28-41. [CrossRef]

53. Alam, M.K. Assessment of Soil Carbon Sequestration and Climate Change Mitigation Potential under Conservation Agriculture Practices in the Eastern Gangetic Plains. Ph.D. Thesis, Murdoch University, Murdoch, Australia, 2018.

54. Kirk, G.J.D.; Olk, D.C. (Eds.) Carbon and nitrogen dynamics in flooded soils. In Proceedings of the Workshop on Carbon and Nitrogen Dynamics in Flooded Soils, Los Baños, Philippines, 19-22 April 1999; International Rice Research Institute: Makati City, Philippines, 2000; p. 188.

55. Patra, P.K.; Saha, N.; Mukherjee, R.; Chakraborty, A.; Sarkar, S.; Mukherjee, D. Influence of tillage techniques and organic matter on carbon and nitrogen transformation in the rice rhizosphere. Appl. Ecol. Environ. Res. 2010, 8, 313-327. [CrossRef]

56. Gunapala, N.; Scow, K.M. Dynamics of soil microbial biomass and activity in conventional and organic farming systems. Soil Biol. Biochem. 1998, 30, 805-816. [CrossRef]

57. Gajri, P.R.; Majumdar, S.P. Tillage. In Fundamentals of Soil Science; Shekhon, G.S., Ed.; ISSS: Pusa, New Delhi 110012, India, 2002; pp. 125-132.

58. Jat, H.S.; Choudhary, M.; Datta, A.; Yadav, A.K.; Meena, M.D.; Devi, R.; Gathala, M.K.; Jat, M.L.; McDonald, A.; Sharma, P.C. Temporal changes in soil microbial properties and nutrient dynamics under climate smart agriculture practices. Soil Tillage Res. 2020, 199, 104595. [CrossRef]

59. Mathew, R.P.; Feng, Y.; Githinji, L.; Ankumah, R.; Balkcom, K.S. Impact of no-tillage and conventional tillage systems on soil microbial communities. Appl. Environ. Soil Sci. 2012. [CrossRef]

60. IRRI (Int Rice Res. Inst.). Annual report for 1963.-Manila, Philippines. Ponnamperuma, F.N. The chemistry of submerged soils. Adv. Agron. 1972, 24, 29-96.

61. Bodelier, P.L.E. Interactions between oxygen releasing roots and microbial processes in flooded soils and sediments. In Root Ecology; de Kroon, H., Visser, E.J.W., Eds.; Springer: Berlin, Germany, 2003; pp. 331-362.

62. Wang, Y.; Hsieh, Y.P. Uncertainties and novel prospects in the study of the soil carbon dynamics. Chemosphere 2002, 49, 791-804. [CrossRef]

63. Yao, H.; Conrad, R.; Wassmann, R.; Neue, H.U. Effect of soil characteristics on sequential reduction and methane production in sixteen rice paddy soils from China, the Philippines, and Italy. Biogeochemistry 1999, 47, 269-295. [CrossRef]

64. Liu, S.; Zhang, Y.; Lin, F.; Zhang, L.; Zou, J. Methane and nitrous oxide emissions from direct-seeded and seedling-transplanted rice paddies in southeast China. Plant Soil 2014. [CrossRef]

65. Sharma, P.K.; De Datta, S.K. Physical properties and processes of puddled rice soils. In Advance in Soil Science; Stewart, B.A., Ed.; Springer: New York, NY, USA, 1986; Volume 5, pp. 139-178.

66. Minami, K.; Fukushi, S. Methods for measuring $\mathrm{N}_{2} \mathrm{O}$ flux from water surface and $\mathrm{N} 2 \mathrm{O}$ dissolved in water from agricultural land. Soil Sci. Plant Nutr. 1984, 30, 495-502. [CrossRef]

67. Majumder, D. $\mathrm{CH}_{4}$ and $\mathrm{N}_{2} \mathrm{O}$ emissions from integrated rice fields.Proposed mitigation strategies. Curr. Sci. 2003, 84, 1-10.

68. Mishra, J.S.; Singh, V.P. Tillage and weed control effects on productivity of a dry seeded rice-wheat system on a Vertisol in Central India. Soil Tillage Res. 2012, 123, 11-20. [CrossRef]

69. Mahajan, G.; Bharaj, T.S.; Timsina, J. Yield and water productivity of rice as affected by time of transplanting in Punjab, India. Agric. Water Manag. 2009, 96, 525-532. [CrossRef] 
70. Islam, A.K.M.S.; Hossain, M.M.; Saleque, M.A. Effect of Unpuddled Transplanting on the Growth and Yield of Dry Season Rice (Oryza sativa L.) in High Barind Tract. Agriculturists 2014, 12, 91-97. [CrossRef]

71. Singh, K.M.; Shahi, B. Popularizing direct seeded rice: Issues and Extension Strategies. SSRN 2015. [CrossRef]

72. Azmi, M.; Chin, D.V.; Vongsaroj, P.; Johnson, D.E. Emerging issues in weed management of direct-seeded rice in Malaysia, Vietnam, and Thailand. In Rice Is Life: Scientific Perspectives for the 21st Century; Toriyama, K., Heong, K.L., Hardy, B., Eds.; International Rice Research Institute: Los Baños, Philippines; Japan International Research Center for Agricultural Sciences: Tsukuba, Japan, 2005; pp. 196-198.

73. de Dios, J.L.; Javier, E.F.; Malabayabas, M.D.; Casimero, M.C.; Espiritu, A.J. An overview on direct-seeding for rice crop establishment in the Philippines. In Rice Is Life: Scientific Perspectives for the 21st Century; Toriyama, K., Heong, K.L., Hardy, B., Eds.; International Rice Research Institute: Los Baños, Philippines; Japan International Research Center for Agricultural Sciences: Tsukuba, Japan, 2005; pp. 189-193.

74. Pandey, S.; Velasco, L. Economics of direct seeding in Asia: Patterns of adoption and research priorities. In Direct Seeding: Research Strategies and Opportunities; Pandey, S., Mortimer, M., Wade, L., Tuong, T.P., Lopez, K., Hardy, B., Eds.; International Rice Research Institute: Los Baños, Philippines, 2002; pp. 3-14.

75. Rao, A.N.; Johnson, D.E.; Sivaprasad, B.; Ladha, J.K.; Mortimer, A.M. Weed management in direct-seeded rice. Adv. Agron. 2007, 93, 153-255.

76. Gianessi, L.; Silvers, C.; Sankula, S.; Carpenter, J. Plant Biotechnology: Current and Potential Impact for Improving Pest Management in U.S. Agriculture: Case Study 27, Herbicide Tolerant Rice; National Centre for Food and Agricultural Policy: Washington, DC, USA, 2002.

77. Ntanos, D. Strategies for rice production and research in Greece. In Research Strategies for Rice Development in Transition Economies; Chataigner, J., Ed.; CIHEAM-IAMM: Montpellier, France, 2001; pp. 115-122.

78. Fischer, A.J.; Antigua, G. Weed management for rice in Latin America and the Caribbean. In Weed Management in Rice; Auld, B.A., Kim, K.U., Eds.; FAO Plant Production and Protection Paper 139; FAO: Rome, Italy, 1996; pp. 159-179.

79. Azmi, M.; Johnson, D.E. Crop establishment options for lowland irrigated rice in relation to weed infestation and grain yield. J. Trop. Agric. Food Sci. 2009, 37, 111-117.

80. Balasubramanian, V.; Hill, J.E. Direct seeding of rice in Asia: Emerging issues and strategic research needs for the 21st century. In Direct Seeding: Research Strategies and Opportunities; Pandey, S., Mortimer, M., Wade, L., Tuong, T.P., Lopez, K., Hardy, B., Eds.; International Rice Research Institute: Los Banos, Philippines, 2002; pp. $15-42$.

81. Stoop, W.; Uphoff, N.; Kassam, A. A review of agricultural research issues raised by the system of rice intensification (SRI) from Madagascar: Opportunities for improving farming systems for resource-poor farmers. Agril. Syst. 2002, 71, 249-274. [CrossRef]

82. Uphoff, N. Agro-ecological alternatives: Capitalising on existing genetic potentials. J. Dev. Stud. 2007, 43, 218-236. [CrossRef]

83. Glover, D. The System of Rice Intensification: Time for an Empirical Turn. NJAS Wagening J. Life Sci. 2011, 57, 217-224. [CrossRef]

84. Noltze, M.; Schwarze, S.; Qaim, M. Impacts of natural resource management technologies on agricultural yield and household income: The system of rice intensification in Timor Leste. Ecol. Econ. 2013, 85, 59-68. [CrossRef]

85. SRI-Rice. Countries. 2016. Available online: http://sri.cals.cornell.edu/countries (accessed on 5 January 2020).

86. FAO. Save and Grow: Maize, Rice and Wheat-A Guide to Sustainable Crop Production; UN Food and Agriculture Organization: Rome, Italy, 2016; pp. 44-47.

87. World Bank. World Bank Institute. 2010. Available online: http://info.worldbank.org/etools/docs/library/ 245848/ (accessed on 5 January 2020).

88. Ladha, J.K.; Kumar, V.; Alam, M.M.; Sharma, S.; Gathala, M.; Chandna, P.; Saharawat, Y.S.; Balasubramanian, V. Integrating crop and resource management technologies for enhanced productivity, profitability, and sustainability of the rice-wheat system in South Asia. In Integrated Crop and Resource Management in the Rice-Wheat System of South Asia; Ladha, J.K., Singh, Y., Erenstein, O., Hardy, B., Eds.; International Rice Research Institute: Los Baños, Philippines, 2009; pp. 69-108.

89. Salahin, N.; Alam, M.K.; Shil, N.C.; Mondol, A.T.M.A.I.; Alam, M.J. Effects of tillage practices and nutrient management on crop productivity and profitability in Jute-T. aman rice- Onion cropping system. Bangladesh J. Agril. Res. 2019, 44(3), 387-399. [CrossRef] 
90. Haque, M.E.; Bell, R.W.; Vance, W.; Mia, N.N. Designing Intensive Crop Sequences for Conservation Agriculture Using Mechanized Planters on Two-Wheel Tractors. In Proceedings of the 4th International Symposium for Farming Systems Design, Lanzhou, China, 19-22 August 2013; Chen, F., Gao, W., Eds.; Gansu Science and Technology Press: Lanzhou, China, 2013; pp. 251-252.

91. Hossen, M.A.; Hossain, M.M.; Bell, R.W.; Haque, M.E.; Rahman, M.A. Development and Validation of Unpuddled Riding-type Rice Transplanter for Wetland Rice Establishment. In Proceedings of the 2nd Conference on Conservation Agriculture for Smallholders (CASH-II), Mymensingh, Bangladesh, 14-16 February 2017; pp. 55-58.

92. Devkota, K.P.; Sudhir-Yadav; Khanda, C.M.; Beebout, S.J.; Mohapatra, B.K.; Singleton, G.R.; Puskur, R. Assessing alternative crop establishment methods with a sustainability lens in rice production systems of Eastern India. J. Clean. Prod. 2020, 244, 118835. [CrossRef]

93. Kumar, V.; Singh, S.; Kumar, R.M.; Sharma, S.; Tripathi, R.; Nayak, A.K.; Ladha, J.K. Growing Rice in Eastern India: New Paradigms of Risk Reduction and Improving Productivity; Mohanty, S., Chengappa, P.G., Mruthyunjaya, Ladha, J.K., Baruah, S., Kannan, E., Manjunatha, A.V.B.T., Eds.; Academic Press: Cambridge, MA, USA, 2017; pp. 221-258.

94. Rao, K.V.R.; Gangwar, S.; Keshri, R.; Chourasia, L.; Bajpai, A.; Soni, K. Effects of Drip Irrigation System for Enhancing Rice (Oryza sativa L.) Yield Under System of Rice Intensification Management. App. Ecol. Environ. Res. 2017, 15, 487-495. [CrossRef]

95. Bansal, R.; Sharma, N.; Soman, P.; Singh, S.; Bhardwaj, A.K.; Pandiaraj, T.; Bhardwaj, R.K. On-Farm Drip Irrigation in Rice for Higher Productivity and Profitability in Haryana, India. Int. J. Curr. Microbiol. App. Sci. 2018, 7, 506-512.

96. Parthasarathi, T.; Vanitha, K.; Mohandass, S.; Vered, E. Evaluation of Drip Irrigation System for Water Productivity and Yield of Rice. Agron. J. 2018, 110, 2378. [CrossRef]

97. Jat, M.L.; Gathala, M.K.; Saharawat, Y.S.; Tetarwal, J.P.; Gupta, R.; Yadvinder, S. Double no-till and permanent raised beds in maize-wheat rotation of north-western Indo-Gangetic Plains of India: Effects on crop yields, water productivity, profitability and soil physical properties. Field Crops Res. 2013, 149, 291-299. [CrossRef]

98. Gebhardt, M.R.; Daniel, T.C.; Schweizer, E.E.; Allmaras, R.R. Conservation tillage. Science 1985, 230, 625-630. [CrossRef] [PubMed]

99. Al-Kaisi, M.M.; Yin, X. Stepwise time response of corn yield and economic return to no tillage. Soil Tillage Res. 2004, 78, 91-101. [CrossRef]

100. Thierfelder, C.; Wall, P.C. Effects of conservation agriculture techniques on infiltration and soil water content in Zambia and Zimbabwe. Soil Tillage Res. 2009, 105, 217-227. [CrossRef]

101. Phillips, R.E.; Blevins, R.L.; Thomas, G.W.; Frye, W.W.; Phillips, S.H. No-tillage agriculture. Science 1980, 208, 1108-1113. [CrossRef]

102. D’Haene, K.; Vermang, J.; Cornelis, W.M.; Leroy, B.L.M.; Schiettecatte, W.; De Neve, S.; Gabriels, D.; Hofman, G. Reduced tillage effects on physical properties of silt loam soils growing root crops. Soil Tillage Res. 2008, 99, 279-290. [CrossRef]

103. Hossain, M.I.; Osaki, M.; Haque, M.S.; Khan, M.M.H.; Rahmatullah, N.M.; Rashid, M.H. Effect of straw management and nitrogen fertilization on root growth and root characteristics of wheat through raised bed system on a low N calcareous soil of Bangladesh. Thai J. Agric. Sci. 2008, 41, 45-52.

104. Lal, R.; Mahboubi, A.A.; Fausey, N.R. Long-term tillage and rotation effects on properties of a central Ohio soil. Soil Sci. Soc. Am. J. 1994, 58, 517-522. [CrossRef]

105. Sharma, R.S.J. Agronomic research in rice-wheat system in Madhya Pradesh. Int. J. Adv. Agric. Res. 1997, 7, 139-157.

106. Mondal, S.; Kumar, S.; Haris, A.A.; Dwivedi, S.K.; Bhatt, B.P.; Mishra, J.S. Effect of different rice establishment methods on soil physical properties in drought-prone, rainfed lowlands of Bihar, India. Soil Res. 2016, 54, 997-1006. [CrossRef]

107. Gathala, M.K.; Ladha, J.K.; Saharawat, Y.S.; Kumar, V.; Kumar, V.; Sharma, P.K. Effect of tillage and crop establishment methods on physical properties of a medium-textured soil under a seven-year rice-wheat rotation. Soil Sci. Soc. Am. J. 2011, 75, 1851-1862. [CrossRef]

108. Nandan, R.; Singh, V.; Singh, S.S.; Kumar, V.; Hazrab, K.K.; Nath, C.P.; Poonia, S.; Malik, R.K.; Bhattacharyya, R.; McDonald, A. Impact of conservation tillage in rice-based cropping systems on soil aggregation, carbon pools and nutrient. Geoderma 2019, 340, 104-114. [CrossRef] [PubMed] 
109. Kumar, R.; Yadav, D.S. Effect of zero and minimum tillage in conjunction with nitrogen management in wheat (Triticum aestivum) after rice (Oryza sativa). Indian J. Agron. 2005, 50, 54-57.

110. Yan, F.; Schubert, S. Soil pH changes after application of plant shoot materials of faba bean and wheat. Plant Soil 2000, 220, 279-287. [CrossRef]

111. Mandal, K.G.; Misra, A.K.; Hati, K.M.; Bandyopadhyay, K.K.; Ghosh, P.K.; Mohanty, M. Rice residuemanagement options and effects on soil properties and crop productivity. Food Agric. Environ. 2004, 2, 224-231.

112. Kumar, B.; Gupta, R.K.; Bhandari, A.L. Soil fertility changes after long-term application of organic manures and crop residues under rice-wheat system. J. Indian Soc. Soil Sci. 2008, 56, 80-85.

113. Houx III, J.H.; Wiebold, W.J.; Fritschi, F.B. Long-term tillage and crop rotation determines the mineral nutrient distributions of some elements in a Vertic Epiaqualf. Soil Tillage Res. 2011, 112, 27-35. [CrossRef]

114. Tiecher, T.; Calegari, A.; Caner, L.; Rheinheimer, D.S. Soil fertility and nutrient budget after 23-years of different soil tillage systems and winter cover crops in a subtropical Oxisol. Geoderma 2017, 308, 78-85. [CrossRef]

115. Selles, F.; Kochhann, R.A.; Denardin, J.E.; Zentner, R.P.; Faganello, A. Distribution of phosphorus fractions in a BrazilianOxisol under different tillage systems. Soil Tillage Res. 1997, 44, 23-34. [CrossRef]

116. Vu, D.T.; Tang, C.; Armstrong, R.D. Tillage system affects phosphorus form and depth distribution in three contrasting Victorian soils. Soil Res. 2009, 47, 33-45. [CrossRef]

117. Beri, V.; Sidhu, B.S.; Bahl, G.S.; Bhat, A.K. Nitrogen and phosphorus transformations as affected by crop residue management practices and their influence on crop yield. Soil Use Manag. 1995, 11, 51-54. [CrossRef]

118. Misra, R.D.; Pandey, D.S.; Gupta, V.K. Crop residue management for increasing the productivity and sustainability in rice-wheat system. In Abstract of Poster Sessions, 2nd ed.; National Academy of Agricultural Sciences and ICAR: New Delhi, India, 1996; p. 42.

119. Pierce, F.J.; Fortin, M.C.; Staton, M.J. Periodic plowing effects on soil properties in a no-till farming system. Soil Sci. Soc. Am. J. 1994, 58, 1782-1787. [CrossRef]

120. Redel, Y.D.; Rubio, R.; Rouanet, J.L.; Borie, F. Phosphorus bioavailability affected by tillage and crop rotation on a Chilean volcanic derived Ultisol. Geoderma 2007, 139, 388-396. [CrossRef]

121. Robbins, S.G.; Voss, R.D. Phosphorus and potassium stratification in conservation tillage systems. J. Soil Water Conserv. 1991, 46, 298-300.

122. Pradhan, P.R.; Pandey, R.N.; Behera, U.K.; Swarup, A.; Datta, S.C.; Dwived, B.S. Tillage and crop residue management practices on crop productivity, phosphorus uptake and forms in wheat (Triticum aestivum)-based cropping systems. Indian J. Agric. Sci. 2011, 81, 1168-1173.

123. Wang, X.B.; Hoogmoed, W.B.; Cai, D.X.; Perdok, U.D.; Oenema, O. Crop residue, manure and fertilizer in dryland maize under reduced tillage in northern China: II Nutrient balances and soil fertility. Nutr. Cycl. Agroecosyst. 2007, 79, 17-34. [CrossRef]

124. Zibilske, L.M.; Bradford, J.M. Tillage effects on phosphorus mineralization and microbial activity. Soil Sci. 2003, 168, 677-685. [CrossRef]

125. Ohno, T.; Erich, S. Inhibitory effects of crop residue-derived organic ligands on phosphate adsorption kinetics. J. Environ. Qual. 1997, 26, 889-895. [CrossRef]

126. Griffith, D.R.; Mannering, J.V.; Moldenhauer, W.C. Conservation tillage in the Eastern cornbelt. J. Soil Water Conserv. 1977, 32, 20-28.

127. Ben Moussa-Machraoui, S.; Errouissi, F.; Ben-Hammonda, M.; Nouira, S. Comparative effects of conventional and no-tillage management on some soil properties under Mediterranean semi-arid conditions in northwestern Tunisia. Soil Tillage Res. 2010, 106, 247-253. [CrossRef]

128. Franzluebbers, A.J.; Hons, F.M. Soil-profile distribution of primary and secondary plantavailable nutrients under conventional and no tillage. Soil Tillage Res. 1996, 39, 229-239. [CrossRef]

129. Tony, J.V.; Janovick, J.D. Potassium placement and tillage system effects on corn response following long-term no-till. Agron. J. 2001, 93, 487-495.

130. Dorneles, E.P.; Lisboa, B.B.; Abichequer, A.D.; Bissani, C.A.; Meurer, E.J.; Vargas, L.K. Tillage, fertilization systems and chemical attributes of a Paleudult. Sci. Agric. 2015, 72, 175-186. [CrossRef]

131. Costa, S.E.V.G.A.; Souza, E.D.; Anghinoni, I.; Flores, J.P.C.; Cao, E.G.; Holzschuh, M.J. Phosphorus and root distribution and corn growth related to longterm tillage systems and fertilizer placement. Rev. Bras. Cienc. Solo 2009, 33, 1237-1247. [CrossRef] 
132. Borges, R.; Mallarino, B.B. Deep banding phosphorus and potassium fertilizer for corn managed with ridge tillage. Soil Sci. Soc. Am. J. 2001, 65, 376-384. [CrossRef]

133. Alam, M.K.; Bell, R.W.; Salahin, N.; Pathan, S.; Mondol, A.T.M.A.I.; Alam, M.J.; Rashid, M.H.; Paul, P.L.C.; Hossain, M.I.; Shil, N.C. Banding of fertiliser improves phosphorus acquisition and yield of zero tillage maize by concentrating phosphorus in surface soil. Sustainability 2018, 10, 3234. [CrossRef]

134. Deubel, A.; Hofmann, B.; Orzessek, D. Long-term effects of tillage on stratification and plant availability of phosphate and potassium in a loess chernozem. Soil Tillage Res. 2011, 117, 85-92. [CrossRef]

135. Rahman, M.S. Yield and Nutrient Uptake by Wheat as Influenced by Tillage and Crop Residues. Ph.D. Thesis, Department of Agricultural Chemistry, Bangladesh Agricultural University, Mymensingh, Bangladesh, 2004.

136. Yadvinder-Singh, S.; Singh, B.; Timsina, J. Crop residue management for nutrient cycling and improving soil productivity in rice based cropping systems in the tropics. Adv. Agron. 2005, 85, 269-407.

137. Mohanty, M.; Painuli, D.K.; Mandal, K.G.; Pachlaniya, N.K.; Misra, A.K. Cracking of a Vertisol as Influenced by Puddling and Residue Management under Rice-Wheat Cropping System. J. Indian Soc. Soil Sci. 2006, 54, 452-460.

138. Bajpai, R.K.; Tripathi, R.P. Evaluation of non-pudding under shallow water tables and alternative tillage methods on soil and crop parameters in a rice- wheat system in Uttar Pradesh. Soil Tillage Res. 2000, 55, 96-106. [CrossRef]

139. Mousavi, S.F.; Yousefi-Moghadam, S.; Mostafazadeh-Fard, B.; Hemmat, A.; Yazdani, M.R. Effect of puddling intensity on physical properties of a silty clay soil under laboratory and field conditions. Paddy Water Environ. 2009, 7, 45-54. [CrossRef]

140. Envirothink. System of Rice Intensification Brings Hope to Global Rice Production. 2014. Available online: https:/envirothink.wordpress.com/2014/09/30/system-of-rice-intensification-brings-hopeto-global-rice-production/ (accessed on 7 September 2018).

141. Kar, I.; Yadav, S.; Mishra, A.; Behera, B.; Khanda, C.; Kumar, V.; Kumar, A. Productivity trade-off with different water regimes and genotypes of rice under nonpuddled conditions in Eastern India. Field Crops Res. 2018, 222, 218-229. [CrossRef] [PubMed]

142. WaterAid in Nepal. Report_-Rainwater Harvesting for Recharging Shallow Groundwater; WaterAid in Nepal: Kathmandu, Nepal, 2011; pp. 19-39.

143. Mainuddin, M.; Maniruzzaman, M.D.; Alam, M.M.; Mojid, M.A.; Schmidt, E.J.; Islam, M.T.; Scobie, M. Water usage and productivity of Boro rice at the field level and their impacts on the sustainable groundwater irrigation in the North-West Bangladesh. Agric. Water Manag. 2020, 240, 106294. [CrossRef]

144. Broadbent, F.E. Plant use of soil nitrogen. In Nitrogen in Crop Production; Hauck, R.D., Ed.; ASA-CSSA-SSA: Madison, WI, USA, 1984; pp. 171-182.

145. Kumar, K.; Goh, K.M. Nitrogen release from crop residues and organic amendments as affected by biochemical composition. Commun. Soil Sci. Plant Anal. 2003, 34, 2441-2460. [CrossRef]

146. Busari, M.A.; Kuka, S.S.; Kaur, A.; Bhatt, R.; Dulazi, A.A. Conservation tillage impacts on soil, crop and the environment. Int. Soil Water Conserv. Res. 2015, 3, 119-129. [CrossRef]

147. Bayer, C.; Mielniczuk, J.; Amado, T.J.C.; Martin-Neto, L.; Fernandes, S.V. Organic matter storage in a sandy loam Acrisol affected by tillage and cropping systems in southern Brazil. Soil Tillage Res. 2000, 54, 101-109. [CrossRef]

148. Islam, A.K.M.S.; Hossain, M.M.; Saleque, M.A.; Rabbani, M.A.; Sarker, R.I. Energy consumption in unpuddled transplanting of wet season rice cultivation in north west region of Bangladesh. Prog. Agric. 2013, 24, 229-237. [CrossRef]

149. Curtin, D.; Francis, G.S.; McCallum, F.M. Decomposition rate of cereal straw as affected by soil placement. Soil Res. 2008, 46, 152-160. [CrossRef]

150. Verhulst, N.; François, I.; Grahmann, K.; Cox, R.; Govaerts, B. Nitrogen use efficiency and optimization of nitrogen fertilization in conservation agriculture. CAB Rev. 2013, 8, 1-19.

151. Blevins, R.L.; Frye, W.W. Conservation tillage: An ecological approach to soil management. Adv. Agron. 1993, 51, 33-78.

152. García-Orenes, F.; Morugán-Coronado, A.; Zornoza, R.; Scow, K. Changes in soil microbial community structure influenced by agricultural management practices in a Mediterranean agro-ecosystem. PLoS ONE 2013, 8, e80522. [CrossRef] [PubMed] 
153. Zhang, B.; He, H.; Ding, X.; Zhang, X.; Zhang, X.; Yang, X.; Filley, T.R. Soil microbial community dynamics over a maize (Zea mays L.) growing season under conventional- and no-tillage practices in a rainfed agroecosystem. Soil Tillage Res. 2012, 124, 153-160. [CrossRef]

154. Kushwaha, C.P.; Srivastava, R.; Singh, K.P. Implications of tillage and residue management on soil microbial biomass, N-mineralization rate and available-N in a dryland agroecosystem. Trop. Ecol. 2000, 41, 123-126.

155. Choudhary, M.; Sharma, P.C.; Jat, H.S.; McDonald, A.J.; Jat, M.L.; Choudhary, S.; Garg, N. Soil biological properties and fungal diversity under conservation agriculture in Indo-Gangetic Plains of India. J. Soil Sci. Plant Nutr. 2018, 18, 1142-1156. [CrossRef]

156. Wang, J.J.; Li, X.Y.; Zhu, A.N.; Zhang, X.K.; Zhang, H.W.; Liang, W.J. Effects of tillage and residue management on soil microbial communities in North China. Plant Soil Environ. 2012, 58, 28-33. [CrossRef]

157. Moore, J.M.; Klose, S.; Tabatabai, M.A. Soil microbial biomass carbon and nitrogen as affected by cropping systems. Biol. Fertil. Soils 2000, 31, 200-210. [CrossRef]

158. Alvarez, R.; Diaz, R.A.; Barbero, N.; Santanatoglia, O.J.; Blotta, L. Soil organic carbon, microbial biomass and CO2-C production from three tillage systems. Soil Tillage Res. 1995, 33, 17-28. [CrossRef]

159. Govaerts, B.; Mezzalama, M.; Unno, Y.; Sayre, K.D.; Luna-Guido, M.; Vanherck, K.; Dendooven, L.; Deckers, J. Influence of tillage, residue management, and crop rotation on soil microbial biomass and catabolic diversity. Appl. Soil Ecol. 2007, 37, 18-30. [CrossRef]

160. Zhu, L.; Hu, N.; Yang, M.; Zhan, X.; Zhang, Z. Effects of different tillage and straw return on soil organic carbon in a rice-wheat rotation system. PLOS ONE 2014, 9, e88900. [CrossRef]

161. Balota, E.L.; Colozzi-Filho, A.; Andrade, D.S.; Dick, R.P. Microbial biomass in soils under different tillage and crop rotation systems. Biol. Fertil. Soils 2003, 38, 15-20. [CrossRef]

162. Alam, M.K.; Bell, R.W.; Haque, M.E.; Kader, M.A. Minimal soil disturbance and increased residue retention increase soil carbon in rice-based cropping systems on the Eastern Gangetic Plain. In Proceedings of the 7th International Symposium on Soil Organic Matter, Adelaide, Australia, 7-11 October 2019.

163. Liu, S.; Zhang, Y.; Zong, Y.; Hu, Z.; Wu, S.; Zhou, J.; Jin, Y.; Zou, J. Response of soil carbon dioxide fluxes, soil organic carbon and microbial biomass carbon to biochar amendment: A meta-analysis. GCB Bioenergy 2016, 8, 392-406. [CrossRef]

164. Bandick, A.K.; Dick, R.P. Field management effects on soil enzyme activities. Soil Biol. Biochem. 1999, 31, 1471-1479. [CrossRef]

165. Jin, K.; Sleutel, S.; Buchan, D.; De Neve, S.; Cai, D.X.; Gabriels, D.; Jin, J.Y. Changes of soil enzyme activities under different tillage practices in the Chinese Loess Plateau. Soil Tillage Res. 2009, 104, 115-120. [CrossRef]

166. Wang, J.B.; Chen, Z.H.; Chen, L.J.; Zhu, A.N.; Wu, Z.J. Surface soil phosphorus and phosphatase activities affected by tillage and crop residue input amounts. Plant Soil Environ. 2011, 57, 251-257. [CrossRef]

167. Rolden, A.; Salinas-García, J.R.; Alguacil, M.M.; Díaz, E.; Caravaca, F. Soil enzyme activities suggest advantages of conservation tillage practices in sorghum cultivation under subtropical conditions. Geoderma 2005, 129, 178-185. [CrossRef]

168. Eivazi, F.; Tabatabai, M.A. Factors affecting glucosidase and galactosidase activities in soils. Soil Biol. Biochem. 1990, 22, 891-897. [CrossRef]

169. Rathore, R.; Dowling, D.N.; Forristal, P.D.; Spink, J.; Cotter, P.D.; Bulgarelli, D.; Germaine, K.J. Crop establishment practices are a driver of the plant microbiota in winter oilseed rape (Brassica napus). Front. Microbiol. 2007, 8, 1489. [CrossRef]

170. Smith, C.R.; Blair, P.L.; Boyd, C.; Cody, B.; Hazel, A.; Hedrick, A.; Kathuria, H.; Khurana, P.; Kramer, B.; Muterspaw, K.; et al. Microbial community responses to soil tillage and crop rotation in a corn/soybean agroecosystem. Ecol. Evol. 2016, 6, 8075-8084. [CrossRef]

171. Venter, Z.S.; Jacobs, K.; Hawkins, H.J. The impact of crop rotation on soil microbial diversity: A meta-analysis. Pedobiologia 2016, 59, 215-223. [CrossRef]

172. Bailey, V.L.; Smith, J.L.; Bolton, H. Fungal-tobacterial ratios in soils investigated for enhanced C sequestration. Soil Biol. Biochem. 2002, 34, 997-1007. [CrossRef]

173. Miura, T.; Niswati, A.; Swibawa, I.G.; Haryani, S.; Gunito, H.; Shimano, S.; Fujie, K.; Kaneko, N. Diversity of fungi on decomposing leaf litter in a sugarcane plantation and their response to tillage practice and bagasse mulching: Implications for management effects on litter decomposition. Microb. Ecol. 2015, 70, 646-658. [CrossRef] [PubMed] 
174. Wang, Z.; Chen, Q.; Liu, L.; Wen, X.; Liao, Y. Responses of soil fungi to 5-year conservation tillage treatments in the drylands of northern China. Appl. Soil Ecol. 2016, 101, 132-140. [CrossRef]

175. Phosri, C.; Polme, S.; Taylor, A.F.; Koljalg, U.; Suwannasai, N.; Tedersoo, L. Diversity and community composition of ectomycorrhizal fungi in a dry deciduous dipterocarp forest in Thailand. Biodivers. Conserv. 2012, 21, 2287-2298. [CrossRef]

176. Maarastawi, S.A.; Frindte, K.; Linnartz, M.; Knief, C. Crop rotation and straw application impact microbial communities in Italian and Philippine soils and the rhizosphere of Zea mays. Front. Microbiol. 2018, 9, 1295. [CrossRef]

177. Yanni, Y.G.; Rizk, R.Y.; Corich, V.; Squartini, A.; Ninke, K.; Philip-Hollingsworth, S.; Orgambide, G.; De Bruijn, F.; Stoltzfus, J.; Buckley, D.; et al. Natural endophytic association between Rhizobium leguminosarum bv. trifolii and rice roots and assessment of its potential to promote rice growth. Plant Soil 1997, 194, 99-114. [CrossRef]

178. Ceja-Navarro, J.A.; Rivera-Orduna, F.N.; Patino-Zúniga, L.; Vila-Sanjurjo, A.; Crossa, J.; Govaerts, B.; Dendooven, L. Phylogenetic and multivariate analyses to determine the effects of different tillage and residue management practices on soil bacterial communities. Appl. Environ. Microbiol. 2010, 76, 3685-3691. [CrossRef]

179. Sun, R.; Li, W.; Dong, W.; Tian, Y.; Hu, C.; Liu, B. Tillage changes vertical distribution of soil bacterial and fungal communities. Front. Microbiol. 2018, 9, 699. [CrossRef]

180. Lynch, J.M.; Whipps, J.M. Substrate flow in the rhizosphere. Plant Soil 1990, 129, 1-10. [CrossRef]

181. Saharawat, Y.S.; Singh, B.; Malik, R.K.; Ladha, J.K.; Gathala, M.; Jat, M.L.; Kumar, V. Evaluation of alternative tillage and crop establishment methods in a rice-wheat rotation in North Western IGP. Field Crops Res. 2010, 116, 260-267. [CrossRef]

182. Raiesi, F. Carbon and $\mathrm{N}$ mineralization as affected by soil cultivation and crop residue in a calcareous wetland ecosystem in central Iran. Agric. Ecosyst. Environ. 2006, 112, 13-20. [CrossRef]

183. Motschenbacher, J.M.; Brye, K.R.; Anders, M.M.; Gbur, E.E.; Slaton, N.A.; White, M.A.E. Long-Term Crop Rotation, Tillage, and Fertility Effects on Soil Carbon and Nitrogen in Dry-Seeded, Delayed-Flood Rice Production Systems. In $\mathrm{CO}_{2}$ Sequestration and Valorization; Morgado, C.R.V., Esteves, V.P.P., Eds.; Intech: London, UK, 2014; pp. 129-156.

184. Sahoo, D.; Rout, K.K.; Mishra, V. Effect of twenty five years of fertilizer application on productivity of rice-rice system. In Longterm Soil Fertility Management through Integrated Plant Nutrient Supply; Swarup, A., Reddy, D.D., Prasad, R.N., Eds.; Indian Institute of Soil Science: Bhopal, India, 1998; pp. 206-214.

185. Witt, C.; Cassman, K.G.; Olk, D.C.; Biker, U.; Liboon, S.P.; Samson, M.I.; Ottow, J.C.G. Crop rotation and residue management effects on carbon sequestration, nitrogen cycling, and productivity of irrigated rice systems. Plant Soil 2000, 225, 263-278. [CrossRef]

186. Ladha, J.K.; Kessel, C.V. Sustaining soil carbon and nitrogen pools for future cereal production. In Proceedings of the 19th World Congress of Soil Science for a Changing World, Bisbane, Australia, 1-6 August 2010.

187. Silgram, M.; Shepherd, M.A. The Effects of Cultivation on Soil Nitrogen Mineralization. Adv. Agron. 1999, 65, 267-311.

188. Malhi, S.S.; Grant, C.A.; Johnston, A.M.; Gill, K.S. Nitrogen Fertilization Management for No-Till Cereal Production in the Canadian Great Plains: A Review. Soil Tillage Res. 2001, 60, 101-122. [CrossRef]

189. Alvarez, R.; Steinbach, H.S. A Review of the effects of tillage systems on some soil physical properties, water content, nitrate availability and crops yield in the Argentine Pampas. Soil Tillage Res. 2009, 104, 1-15. [CrossRef]

190. Meena, J.R.; Behera, U.K.; Chakraborty, D.; Sharma, A.R. Tillage and residue management effect on soil properties, crop performance and energy relations in greengram (Vigna radiata L.) under maize-based cropping systems. Int. Soil Water Conserv. Res. 2015, 3, 261-272. [CrossRef]

191. Alam, M.K.; Biswas, W.K.; Bell, R.W. Increases in soil sequestered carbon under conservation agriculture cropping decrease the estimated greenhouse gas emissions of wetland rice using life cycle assessment. J. Clean. Prod. 2019, 224, 72-84. [CrossRef]

192. Alam, M.K.; Biswas, W.K.; Bell, R.W. Greenhouse gas implications of novel and conventional rice production technologies in the Eastern-Gangetic plains. J. Clean. Prod. 2016, 112, 3977-3987. [CrossRef]

193. Ryan, M.G.; Law, B.E. Interpreting, measuring, and modeling soil respiration. Biogeochem 2005, 73, 3-27. [CrossRef] 
194. Yoshinari, T. Emissions of $\mathrm{N}_{2} \mathrm{O}$ from various environments-The use of stable isotope composition of $\mathrm{N}_{2} \mathrm{O}$ as tracer for the studies of $\mathrm{N}_{2} \mathrm{O}$ biogeochemical cycling. In Denitrification in Soil and Sediment; Sorensen, J., Ed.; Plenum Press: New York, NY, USA, 1990; pp. 129-144.

195. Tsuruta, H. Methane and nitrous oxide emissions from a rice paddy field. In Proceedings of the World Congress of Soil Science, Bangkok, Thailand, 14-21 August 2002.

196. Ladha, J.K.; Rao, A.N.; Raman, A.K.; Padre, A.T.; Dobermann, A.; Gathala, M.; Kumar, V.; Saharawat, Y.; Sharma, S.; Piepho, H.P.; et al. Agronomic improvements can make future cereal systems in South Asia far more productive and result in a lower environmental footprint. Glob. Chang. Biol. 2016, 22, 1054-1074. [CrossRef]

197. Cassman, K.G.; De Datta, S.K.; Olk, D.C.; Alcantara, J.; Samson, M.; Descalsota, J.P.; Dizon, M. Yield decline and the nitrogen economy of long-term experiments on continuous irrigated rice systems in the tropics. In Sustainable Management of Soils; Lal, R., Stewart, B.A., Eds.; Lewis CRC Publishers: Boca Raton, FL, USA, 1995; pp. 181-222.

198. Wassmann, R.; Neue, H.U.; Ladha, J.K.; Aulakh, M.S. Mitigating greenhouse gas emissions from rice-wheat cropping systems in Asia. Environ. Dev. Sustain. 2004, 6, 65-90. [CrossRef]

199. Pathak, H.; Tewari, A.N.; Sankhyan, S.; Dubey, D.S.; Mina, U.; Singh, V.K.; Jain, N.; Bhatia, A. Direct-seeded rice: Potential, performance and problems-a review. Curr. Adv. Agric. Sci. 2011, 3, 77-88.

200. Harada, H.; Kobayashi, H.; Shindo, H. Reduction in greenhouse gas emissions by no-tilling rice cultivation in Hachirogata polder, northern Japan: Life-cycle inventory analysis. Soil Sci. Plant Nutr. 2007, 53, 668-677. [CrossRef]

201. Ko, J.Y.; Kang, H.W. The effects of cultural practices on methane emission from rice fields. Nutr. Cycl. Agroecosyst. 2000, 58, 311-314. [CrossRef]

202. Pathak, H.; Sankhyan, S.; Dubey, D.S.; Bhatia, A.; Jain, N. Dry direct-seeding of rice for mitigating greenhouse gas emission: Field experimentation and simulation. Paddy Water Environ. 2012, 11, 593-601. [CrossRef]

203. Pathak, H.; Aggarwal, P.K. (Eds.) Low Carbon Technologies for Agriculture: A Study on Rice and Wheat Systems in the Indo-Gangetic Plains; Indian Agricultural Research Institute: New Delhi, India, 2012.

204. Hou, H.; Peng, S.; Xu, J.; Yang, S.; Mao, Z. Seasonal variations of $\mathrm{CH}_{4}$ and $\mathrm{N}_{2} \mathrm{O}$ emissions in response to water management of paddy fields located in southeast China. Chemosphere 2012, 89, 884-892. [CrossRef]

205. Ishibashi, E.; Yamamoto, S.; Akai, N.; Tsuruta, H. The influence of no-tilled direct seeding cultivation on green-house gas emissions from rice paddy fields in Okayama, Western Japan. 4. Major factors controlling nitrous oxide emission from rice paddy fields under no-till direct seeding cultivation. Jpn. J. Soil Sci. Plant Nutr. 2007, 78, 453-463.

206. Smith, K.A. The impact of agriculture and other land uses on emissions of methane and nitrous oxide and nitric oxides. Environ. Sci. 2005, 2, 101-108. [CrossRef]

207. Neue, H.-U. Methane emission from rice fields. BioScience 1993, 43, 466-473. [CrossRef]

208. Cai, Z.; Xing, G.; Yan, X.; Xu, H.; Tsuruta, H.; Yagi, K.; Minami, K. Methane and nitrous oxide emissions from rice paddy fields as affected by nitrogen fertilisers and water management. Plant Soil 1997, 196, 7-14. [CrossRef]

209. Adviento-Borbe, M.A.; Pittelkow, C.M.; Anders, M.; van Kessel, C.; Hill, J.E.; McClung, A.M.; Linquist, B.A. Optimal fertilizer $\mathrm{N}$ rates and yield-scaled global warming potential in drill seeded rice. J. Environ. Qual. 2013, 42, 1623-1634. [CrossRef] [PubMed]

210. Sass, R.L.; Denmead, O.T.; Conrad, R.; Freney, J.R.; Klug, M.; Minami, K.; Mosier, A.R.; Neue, H.U.; Rennenberg, H.; Su, W.H.; et al. Exchange of methane and other trace gases in rice cultivation. Ecol. Bull. 1992, 42, 199-206.

211. Johnson, K.; Huyler, M.; Westberg, H.; Lamb, B.; Zimmerman, P. Communications: Measurement of Methane Emissions from Ruminant Livestock Using a SF6 Tracer Technique. Environ. Sci. Technol. 1994, 28, 359-362. [CrossRef] [PubMed]

212. Ratering, S.; Conrad, R. Effects of short-term drainage and aeration on the production of methane in submerged rice soil. Glob. Chang. Biol. 1998, 4, 397-407. [CrossRef]

213. Orchard, V.A.; Cook, F.J. Relationship between soil respiration and soil moisture. Soil Biol. Biochem. 1983, 15, 447-453. [CrossRef]

214. Latey, J.; Valoras, N.; Focht, D.D.; Ryden, J.C. Nitrous oxide production and reduction during denitrification as affected by redox potential. Soil Sci. Soc. Am. J. 1981, 45, 727-730. [CrossRef] 
215. Flessa, H.; Beese, F. Effects of sugarbeet residue on soil redox potential and nitrous oxide emission. Soil Sci. Soc. Am. J. 1995, 59, 1044-1051. [CrossRef]

216. Xing, G.X.; Cao, Y.C.; Shi, S.L.; Sun, G.Q.; Du, L.J.; Zhu, J.G. Denitrification in underground saturated soil in a rice paddy region. Soil Biol. Biochem. 2002, 34, 1593-1598. [CrossRef]

217. Xing, G.X.; Zhao, X.; Xiong, Z.Q.; Yan, X.Y.; Xua, H.; Xie, Y.X.; Shi, S.L. Nitrous oxide emission from paddy fields in China. Acta Ecol. Sin. 2009, 29, 45-50. [CrossRef]

218. Yan, X.; Shi, S.; Du, L.; Xing, G. Pathways of N2O emission from rice paddy soil. Soil Biol. Biochem. 2000, 32, 437-440. [CrossRef]

219. Qin, Y.; Liu, S.; Guo, Y.; Liu, Q.; Zou, J. Methane and nitrous oxide emissions from organic and conventional rice cropping systems in Southeast China. Biol. Fertil. Soils 2010, 46, 825-834. [CrossRef]

220. Abao, E.B., Jr.; Bronson, K.F.; Wassmann, R.; Singh, U. Simultaneous records of methane and nitrous oxide emissions in rice-based cropping systems under rain fed conditions. Nutr. Cycl. Agroecosyst. 2000, 58, 131-139. [CrossRef]

221. Aulakh, M.S.; Khera, T.S.; Doran, J.W.; Bronson, K.F. Denitrification, $\mathrm{N}_{2} \mathrm{O}$ and $\mathrm{CO}_{2}$ fluxes in rice-wheat cropping system as affected by crop residues, fertilizer $\mathrm{N}$ and legume green manure. Biol. Fertil. Soils 2001, 34, 375-389. [CrossRef]

222. Adhya, T.K.; Rath, A.K.; Gupta, P.K.; Rao, V.R.; Das, S.N.; Parida, K.M.; Parashar, D.C.; Sethunathan, N. Methane emission from flooded rice fields under irrigated conditions. Biol. Fertil. Soils 1994, 18, 245-248. [CrossRef]

223. Yagi, K.; Tsuruta, H.; Kanda, K.I.; Minami, K. Effect of water management on methane emission from a Japanese rice paddy field: Automated methane monitoring. Glob. Biogeochem. Cycles 1996, 10, 255-267. [CrossRef]

224. Yagi, K.; Miami, K. Spatial and temporal variations of methane emissions from rice paddy fields. In Biogeochemistry of Global Change; Oremland, R.S., Ed.; Chapman and Hall: Norwell, MA, USA, 1990; pp. 353-368.

225. Firestone, M.K.; Davidson, E.A. Microbiological Basis of NO and N2O Production and Consumption in Soils. In Exchange of Trace Gases between Terrestrial Ecosystems and the Atmosphere; Andreae, M.O., Schimel, D.S., Eds.; John Willey and Sons: New York, NY, USA, 1989; pp. 7-21.

226. Chen, D.; Wang, M.; Shuangguan, X.; Huang, J.; Rasmussen, R.A.; Khalil, M.K.A. Methane emission from paddy fields in the Southwest China. Adv. Earth Sci. 1993, 8, 47-54.

227. Trolldenier, G. Methanogenesis during rice growth as related to the water regime between crop seasons. Biol. Fertil. Soils 1995, 19, 84-86. [CrossRef]

228. Wassmann, R.; Papen, H.; Rennenberg, H. Methane emissions from rice Paddies and Possible Mitigation Strategies. Chemosphere 1993, 26, 201-217. [CrossRef]

229. Singh, J.S.; Singh, S.; Raghubanshi, A.S.; Singh, S.; Kashyap, A.K. Methane flux from rice/wheat agroecosystems as affected by crop phenology, fertilization and water level. Plant Soil 1996, 183, 323-327. [CrossRef]

230. Zheng, X.H.; Wang, M.X.; Wang, Y.S.; Heyer, J.; Kogge, M.; Papen, H.; Jin, J.S.; Li, L.T. $\mathrm{N}_{2} \mathrm{O}$ and $\mathrm{CH}_{4}$ emissions from rice paddies in Southeast China. Chin. J. Atmos. Sci. 1997, 21, 167-174.

231. Khalil, M.A.K.; Rasmussen, R.A.; Shearer, M.J.; Chen, Z.L.; Yao, H.; Yang, J. Emissions of methane, nitrous oxide, and other trace gases from rice fields in China. J. Geophys. Res. Atmos. 1998, 103, 25241-25250. [CrossRef]

232. Mitra, S.; Jain, M.C.; Kumar, S.; Bandyopadhyay, S.K.; Kalra, N. Effect of rice cultivars on methane emission. Agric. Ecosyst. Environ. 1999, 73, 177-183. [CrossRef]

233. Debnath, G.; Jain, M.C.; Kumar, S.; Sarkar, K.; Sinha, S.K. Methane emissions from rice fields amended with biogas slurry and farm yard manure. Clim. Chang. 1996, 33, 97-109. [CrossRef]

234. Jain, M.C.; Kumar, K.; Wassmann, R.; Mitra, S.; Singh, S.D.; Singh, J.P.; Singh, R.; Yadav, A.K.; Gupta, S. Methane emissions from irrigated rice fields in Northern India (New Delhi). Nutr. Cycl. Agroecosyst. 2000, 58, 75-83. [CrossRef]

235. Verhulst, N.; Govaerts, B.; Verachtert, E.; Castellanos-Navarrete, A.; Mezzalama, M.; Wall, P.; Deckers, J.; Sayre, K.D. Conservation Agriculture, Improving Soil Quality for Sustainable Production Systems? In Advances in Soil Science: Food Security and Soil Quality; Lal, R., Stewart, B.A., Eds.; CRC Press: Boca Raton, FL, USA, 2010; pp. 137-208. 
236. Conrad, R. Control of microbial methane production in wetland rice fields. Nutr. Cycl. Agroecosyst. 2002, 64, 59-69. [CrossRef]

237. Breidenbach, B.; Brenzinger, K.; Brandt, F.B.; Blaser, M.B.; Conrad, R. The effect of crop rotation between wetland rice and upland maize on the microbial communities associated with roots. Plant Soil 2017, 419, 435-445. [CrossRef]

238. Talla, A.; Jena, S.N. Evaluation of crop establishment and weed management practices on growth and yield parameters of rice under rainfed conditions. Curr. Biot. 2014, 8, 257-269.

239. Hugar, A.Y.; Chandrappa, H.; Jayadeva, H.M.; Sathish, A.; Mallikarjun, G.B. Influence of different establishment methods on yield and economics of rice. Agric. Sci. Dig. 2009, 29, 202-205.

240. Jayadeva, H.M.; Prabhakara Setty, T.K. Influence of crop establishment techniques and sources of nutrients on productivity, energetics and economics of rice. Oryza 2008, 45, 166-168.

241. Chandrapala, A.G. Productivity as Influenced by Rice Crop Establishment Methods and Nutrient Management (S and Zn). Ph.D. Thesis, Acharya N.G. Ranga Agricultural University, Hyderabad, India, 2009.

242. Mondol, A.P.; Biswas, P.K.; Islam, S. Performance of System of Rice Intensification with Conventional Method of Rice Cultivation. Bangladesh Agron. 2017, 20, 75-80. [CrossRef]

243. Sato, S.; Uphoff, N. A review of on-farm evaluations of system of rice intensification methods in Eastern Indonesia. CAB Rev. Perspect. Agric. Vet. Sci. Nutr. Nat. Resour. 2007, 2, 54. [CrossRef]

244. Ceesay, M.; Reid, W.S.; Fernandes, E.C.M.; Uphoff, N. The effects of repeated soil wetting and drying on lowland rice yield with System of Rice Intensification (SRI) methods. Int. J. Agric. Sustain. 2006, 4, 5-14. [CrossRef]

245. Sinha, S.K.; Talati, J. Productivity impacts of the system of rice intensification (SRI): A case study in West Bengal, India. Agric. Water Manag. 2007, 87, 55-60. [CrossRef]

246. Kabir, H.; Uphoff, N. Results of disseminating the System of Rice Intensification with farmer field school methods in northern Myanmar. Exp. Agric. 2007, 43, 463-476. [CrossRef]

247. Kumar, N.S. Crop Establishment Techniques on Growth Yield and Economics of Rice. Am. Int. J. Res. Form. Appl. Nat. Sci. 2015, 12, 49-51.

248. Kumar, S.S. Productivity of Hybrid Rice as Influenced by Methods of Establishment, Management of Water, Weed and Nutrients. MSc. Thesis, Tamil Nadu Agricultural University, Coimbatore, India, 2002.

249. Satyanarayana, A.; Babu, K.S. Manual of System of Rice Intensification (SRI) A Revolutionary Method of Rice Cultivation; Acharya N. G. Ranga Agricultural University: Hyderabad, India, 2004.

250. Bhowmick, M.K.; Duary, B.; Kundu, C.; Dhara, M.C.; Biswas, P.K. Challenges of Livelihood and Inclusive Rural Development in the Era of Globalization; New Delhi Publishers: New Delhi, India, 2013; pp. 401-417.

251. Haque, M.E.; Bell, R.W.; Vance, W.H.; Rahman, M.M.; Mia, N.N. Transplanted rice in conservation agriculturehow is it possible? In Proceedings of the 6th World Congress of Conservation Agriculture, Winnipeg, MB, Canada, 22-26 June 2014; Available online: www.ctic.org/WCCA/Proceedings (accessed on 10 February 2019).

252. Begum, M.; Hossain, M.M.; Rahman, M.M.; Hashem, A.; Bell, R.W.; Haque, M.E. On-farm non-puddled rice yield response to crop residue retention. In Proceedings of the 2nd Conference on Conservation Agriculture for Smallholders (CASH-II), Mymensingh, Bangladesh, 14-16 February 2017; Haque, M.E., Bell, R.W., Vance, W.H., Eds.; pp. 75-76.

253. Berkhout, E.; Glover, D.; Kuyvenhoven, A. On-farm impact of the System of Rice Intensification (SRI): Evidence and knowledge gaps. Agric. Syst. 2015, 132, 157-166. [CrossRef]

254. Sumberg, J.; Andersson, J.; Giller, K.E.N.; Thompson, J. Response to 'Combining sustainable agricultural production with economic and environmental benefits'. Geogr. J. 2013, 179, 183-185. [CrossRef]

255. Chauhan, B.S.; Singh, R.G.; Mahajan, G. Ecology and management of weeds under conservation agriculture: A review. Crop Prot. 2012, 38, 57-65. [CrossRef]

256. Willocquet, L.; Fernandez, L.; Savary, S. Effect of various crop establishment methods practiced by Asian farmers on epidemics of rice sheath blight caused by Rhizoctonia solani. Plant Pathol. 2000, 49, 346-354. [CrossRef]

257. Castilla, N.P.; Leaño, R.M.; Elazegui, F.A.; Teng, P.S.; Savary, S. Effects of plant contacts, inoculation pattern, leaf wetness regime, and nitrogen supply on inoculum efficiency in rice sheath blight. J. Phytopathol. 1996, 144, 187-192. [CrossRef] 
258. Pandey, S.; Velasco, L.E.; Suphanchalmat, N. Economics of direct seeding in northern Thailand. In Direct Seeding: Research Strategies and Opportunities; Pandey, S., Mortimer, M., Wade, L., Tuong, T.P., Lopez, K., Hardy, B., Eds.; International Rice Research Institute: Los Baños, Philippines, 2002; pp. 139-150.

259. Jha, A.K.; Singh, K.M.; Meena, M.S.; Singh, R.K.P. Constraints of rainfed rice production in eastern India: An Overview. SSRN Electron. J. 2012, 1-9. [CrossRef]

260. Singh, S.; Singh, G. Evaluation of different methods of establishment in wheat (Triticum aestivum) after different methods of rice (Oryza sativa) establishment. Pantnagar J. Res. 2007, 5, 36-40.

261. Jha, A.K.; Sharma, R.S.; Vishwakarma, S.K. Development of resource conservation techniques for tillage and sowing management in rice-wheat cropping system under irrigated production system of Kymore Plateau and Satpura hill zone of Madhya Pradesh. JNKVV Res. J. 2007, 41, 26-31.

262. Jha, A.K.; Kewat, M.L.; Upadhyay, V.B.; Vishwakarma, S.K. Effect of tillage and sowing methods on productivity, economics and energetic of rice (oryza sativa L.)-wheat (Triticum aestivum) cropping system. Indian J. Agron. 2011, 56, 35-40.

263. Durga, A.R.; Kumar, D.S. Economic Analysis of the System of Rice Intensification: Evidence from Southern India. Bangladesh Dev. Stud. 2013, 1, 79-93.

264. Rana, M.M.; Al Mamun, M.A.; Zahan, A.; Zahan, A.; Ahmed, M.N.; Jalil Mridha, M.A. Effect of planting methods on the yield and yield attributes of short duration Aman rice. Am. J. Plant Sci. 2014, 5, 251-255. [CrossRef]

265. Haque, M.E.; Bell, R.W. Partially mechanized nonpuddled rice establishment: On-farm performance and farmers' perceptions. Plant Prod. Sci. 2019, 22, 23-45. [CrossRef]

266. Kaur, J.; Singh, A. Direct Seeded Rice: Prospects, Problems/Constraints and Researchable Issues in India. Curr. Agric. Res. 2017, 5, 13-32. [CrossRef]

267. Singh, S.; Bhushan, L.; Ladha, J.K.; Gupta, R.K.; Rao, A.N.; Sivaprasad, B. Weed management in dry-seeded rice (Oryza sativa) cultivated in the furrow-irrigated raised-bed planting system. Crop Prot. 2006, 25, 487-495. [CrossRef]

268. Singh, S.; Chhokar, R.S.; Gopal, R.; Ladha, J.K.; Gupta, R.K.; Kumar, V.; Singh, M. Integrated weed management: A key to success for direct-seeded rice in the Indo-Gangetic Plains. In Integrated Crop and Resource Management in the Rice-Wheat System of South Asia; Ladha, J.K., Singh, Y., Erenstein, O., Hardy, B., Eds.; International Rice Research Institute: Los Banos, Philippines, 2009; pp. 261-278.

269. Jat, M.L.; Kamboj, B.R.K.; Sidhu, H.S.; Singh, M.; Bana, A.; Bishnoi, D.; Gathala, M.; Saharawat, Y.S.; Kumar, V.; Kumar, A.; et al. Operational Manual for Turbo. Happy Seeder-Technology for Managing Crop Residues with Environmental Stewardship; International Maize and Wheat Improvement Center (CIMMYT); Indian Council of Agricultural Research (ICAR): New Delhi, India, 2013; p. 28.

270. Kirk, G.J.D.; Bajita, J.B. Root induced iron oxidation, $\mathrm{pH}$ changes and zinc solubilization in the rhizosphere of lowland rice. New Phytopathol. 1995, 131, 129-137. [CrossRef]

271. Vermeulen, H. Evaluation of the aerobic rice technology: Three years of experiments in the Philippines. Internship Thesis, Plant Production Systems (WUR), International Rice Research Institute, Los Baños, Philippines, 2007.

272. Setter, T.I.; Laureles, E.V.; Mazaredo, A.M. Lodging reduces yield of rice by self-shading and reduction of photosynthesis. Field Crops Res. 1997, 49, 95-106. [CrossRef]

273. Bonman, J.M.; Leung, H. Breeding for durable resistance to rice blast disease-dream or reality? Phytopathology 2004, 93, 113.

274. Bonman, J.M. Durable resistance to rice blast disease-environmental influences. Euphytica 1992, 63, $115-123$. [CrossRef]

275. Soleri, D.; Cleveland, D.A.; Glasgow, G.; Sweeney, S.H.; Cuevas, F.A.; Fuentes, M.R.; Humberto Rios, L. Testing assumptions underlying economic research on transgenic food crops for Third World farmers: Evidence from Cuba, Guatemala and Mexico. Ecol. Econ. 2008, 67, 667-682. [CrossRef]

276. Sapkota, T.B.; Jat, R.K.; Singh, R.G.; Jat, M.L.; Stirling, C.M.; Jat, M.K.; Bijarniya, D.; Kumar, M.; Yadvinder-Singh; Saharawat, Y.S.; et al. Soil organic carbon changes after seven years of conservation agriculture in a rice-wheat system of the eastern Indo-Gangetic Plains. Soil Use Manag. 2017. [CrossRef]

(C) 2020 by the authors. Licensee MDPI, Basel, Switzerland. This article is an open access article distributed under the terms and conditions of the Creative Commons Attribution (CC BY) license (http://creativecommons.org/licenses/by/4.0/). 